Article

\title{
Investigating the Performance of Enhanced Permeable Groins in Series
}

\author{
Manoochehr Shokrian Hajibehzad ${ }^{1}$, Mahmood Shafai Bejestan ${ }^{2}\left(\mathbb{D}\right.$ and Vito Ferro ${ }^{3, *(D)}$ \\ 1 Department of Civil Engineering, Islamic Azad University Miandoab Branch, Miandoab 5936159351, Iran; \\ m.shokrian65@gmail.com \\ 2 Department of Water Structures, Shahid Chamran University of Ahvaz, Ahvaz 6135783151, Iran; \\ m_shafai@yahoo.com \\ 3 Department of Earth and Marine Science, University of Palermo, Via Archirafi 20, 90128 Palermo, Italy \\ * Correspondence: vito.ferro@unipa.it; Tel.: +39-091-23897068
}

Received: 8 November 2020; Accepted: 11 December 2020; Published: 16 December 2020

check for updates

\begin{abstract}
The enhanced permeable groin is a novel eco-friendly and cost-effective technique for bank protection and restoration of meander bends. The behavior of bed deformations due to the distance between the structures has to be studied to design enhanced permeable groins in series properly. In this study, scour morphologies around enhanced permeable groins in series, characterized by four different distances and located in a $180^{\circ}$ mild flume bend, for clear water conditions were investigated. The analysis indicated that scour geometrical patterns such as the maximum scour depth nearby the structures and the maximum deposition height between them are strongly affected by the distance between the groins. The results revealed that the maximum scour depth around the structures increases with the distance between structures, the scour holes develop towards the outer bank and create a series of pools that can lead to the bank collapse. All experiments, carried out with different structure distances, demonstrated that the location of thalweg effectively shifted towards the middle of the channel and near the inner bank for high and low particle Froude numbers, respectively. As a general result, a distance between enhanced permeable groins equal to four times the effective length of the structure is recommended for a $180^{\circ}$ mild flume bend for the investigated particle Froude numbers. Finally, a general design guideline is presented to a proper design of enhanced permeable groins in series.
\end{abstract}

Keywords: river bend; river restoration; scour; bank protection; enhanced permeable groin

\section{Introduction}

Many of the rivers in nature take a meandering form, including arc-shaped intervals characterized by erosion at the outer banks and deposition of point bars at the inner-banks [1]. The intense erosion of the outer bank is one of the main reasons for the unpredictable lateral migration of meandering rivers that can lead to the destruction of agricultural lands, roads, bridges, and other engineering structures [2].

The most applied method of river restoration to protect the outer bank from erosion is the use of different types of groins. Impermeable groins create large scale horizontal eddies and cause excessive sedimentation along the outer bank, which has negative effects on the river's environmental conditions [3]. Over the last few decades, the use of environmentally friendly structures has become a priority in river engineering due to the growing importance of environmental issues. Rock vanes, j-hook vanes, cross-vanes, W-weirs, triangular vanes, and enhanced permeable groins are eco-friendly and cost-effective structures that can be used as a long-term solution to protect the river environment. 
These structures are usually made of stone and timber and positioned with a low angle to the outer bank [4-9].

Numerous studies have been performed on the performance of groin-type structures in series. The effect of the approaching velocity on the flow behavior around a series of groins in a rectangular flume was investigated by Uijttewaal et al. [10]. The results indicated that decreasing the approaching velocity did not affect the flow behavior around the structures, while reducing the flow depth shifted the center of the circulation cell near the channel middle.

Fukuoka et al. [11] investigated the scour-deposition mechanism around a series of spur dikes. They reported that the aspect ratio is a significant parameter that affects bed topography and flow behavior close to the structures.

Hayashida et al. [12] performed experimental tests to study the effect of distance variations between the different types of groins. They stated that a group of straight groins generate the maximum bed levels in every embayment compared to the T- and L-shaped groins.

Pandey [13] reported that in the case with two subsequent groins in a rectangular straight channel, the maximum scour depth always develops at the upstream side of the first groin and its location was in the zone near the tip of the groin at the upstream side.

Tominaga and Sadat [14] investigated bed deformation pattern around a group of double groins. Four types of pile groins were installed upstream of the structure to reduce scour around the first groin. The results revealed that the intense downward velocity components were the main cause of the local scouring near the first groin and the pile groups diminished shear stresses. Furthermore, Tominaga and Sadat [14] analyzed the effect of permeable and impermeable groins combination on bed topography variations and recognized that the scour depth declined as the distance between the structures decreased from 7 to 4 times the length of the groin.

Dey et al. [15] performed a series of experimental tests to study the scour-deposition mechanism in a $180^{\circ}$ bend in the presence of a group of submerged vanes. The results showed that the submerged vanes have better performance in reducing scour near the outer bank when the structures are placed at an angle of $15^{\circ}$ relative to the outer bank.

Gu et al. [16] studied the effects of distance variation between the threshold of non-submerged twin spur dikes with the ipsilateral and orthogonal layout in a straight rectangular channel from both numerical and experimental points of view. They proposed a generalized relationship to compute the spacing threshold that applies only to the straight rectangular channel.

Triangular vanes, which have been studied in recent years, are an eco-friendly technique to protect the outer bank in meander bends and to develop aquatic habitats. They are installed at a slight angle $\left(15^{\circ}-20^{\circ}\right)$ relative to the tangent of the outer bank [3]. Bhuiyan et al. [3] investigated the flow pattern and the scour-deposition mechanisms around the triangular vanes connected to the outer bank under live bed conditions. They found that when triangular vanes are installed individually or in groups in the outer bank, the scour holes near the outer bank are filled, and the thalweg relocates toward the center of the channel.

The scour-deposition pattern around the triangular vanes in series were studied in a $90^{\circ}$ mild flume bend by Bahrami Yarahmadi and Shafai Bajestan [17] for the clear water condition. The results showed that the maximum scour depth occurred at the end of the structures and when triangular vanes are used in series the distance between the vanes should not be greater than 5 times the effective length of the structure.

In a previous paper, Ferro et al. [18] studied the ability of a new structure, which is a combination of the permeable groin and triangular vane attached to the inner side of the groin, to protect banks in meander bends. This structure, named enhanced permeable groin (EPG), can improve the sedimentation between two consecutive EPGs. These experimental runs were carried out in a $180^{\circ}$ mild laboratory flume bend for the clear water condition and using nine different combinations of permeable groin with triangular vane include three different effective lengths and three angles of the vane. According to these experimental results, a single permeable groin cannot provide a proper sediment deposition 
zone near the outer bank to protect it from erosion while the single EPG is characterized by a good performance of the outer bank protection.

Enhanced permeable groins are eco-friendly and cost-effective hydraulic structures applied for bank protection and restoration of meander bends. However, there are shortcomings in the design of this structure in the series. Therefore, the main goal of this paper is to study the effect of the distance variations between enhanced permeable groins in series on the bed topography changes under various hydraulic conditions.

\section{Materials and Methods}

\section{Experimental Setup}

The experimental runs were performed in a flume bend with a central angle of $180^{\circ}$ in the laboratory of river models of Shahid Chamran University of Ahvaz (Figure 1). The width of the flume was $0.6 \mathrm{~m}$, the radius of internal and external curvatures was 1.8 and $2.4 \mathrm{~m}$, respectively.

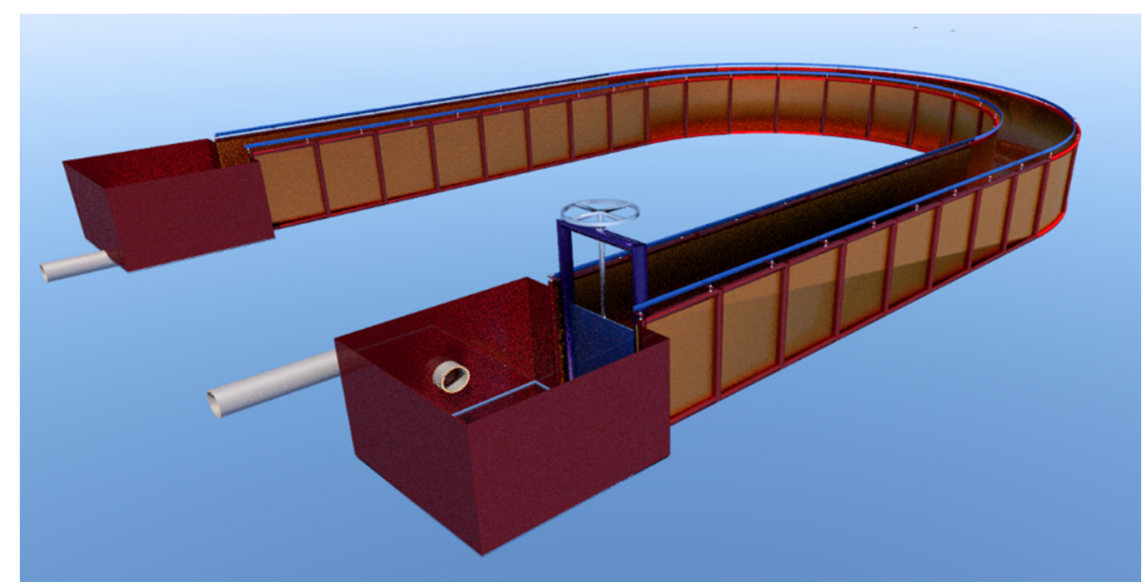

(a)

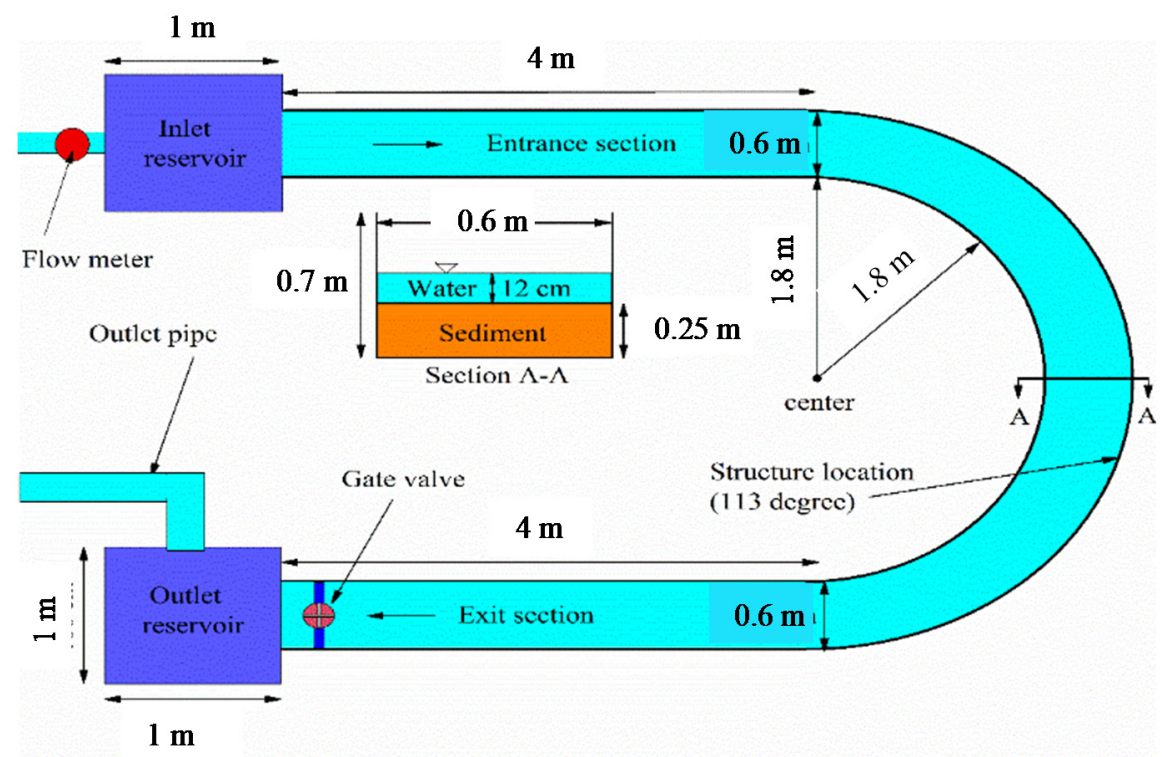

(b)

Figure 1. (a) 3D view; and (b) a schematic plan of the channel bend used in this investigation. 
Based on the classification of Blanckaert [19], the bend used in the present study is in the group of bends with a medium curvature. According to previous studies, the strength of the circulation cells in the case of vertical walls is higher than in inclined or angled walls. For this reason, in the present study, vertical walls (made of iron sheets) were used for the flume to consider the critical conditions. For all experiments, one type of sand with a median diameter $d_{50}$ of $0.00088 \mathrm{~m}$ and a non-uniform coefficient of 1.78 was used, which was poured to a thickness of $0.25 \mathrm{~m}$ along the flume bed. The flow rate was measured by an electromagnetic flowmeter with an accuracy of $0.5 \%$ of the passing flow, which was installed on the inlet pipe to the flume's relaxing tank. The water depth was regulated by a sliding valve located at the outlet of the flow. The water depth at the straight inlet section of the flume was $0.12 \mathrm{~m}$ and was considered the same for all experiments. The effective length of the enhanced permeable groin $L_{e}$ was selected to be $23 \%$ of the flume width $(0.14 \mathrm{~m})$. The EPG (Figure 2) consisted of a permeable part having a length $L_{p}$ of $0.09 \mathrm{~m}$ and a triangular-shaped vane with a length $L_{t}$ of $0.05 \mathrm{~m}$ and, as a consequence, the ratio $L_{t} / L_{p}$ was equal to 0.55 .

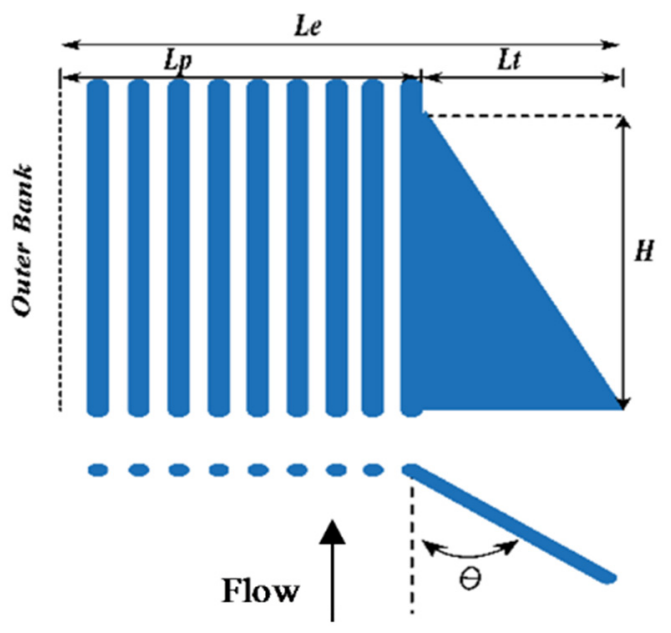

Figure 2. Enhanced permeable groin and its parameters.

The angle $\theta$ of the triangular vane, relative to the tangent of the outer bank and in the upward direction of the flow, was $50^{\circ}$ and was selected based on the study of Ferro et al. [18]. The triangular vane and the permeable part of the structure were made of $0.005 \mathrm{~m}$ thick Plexiglas sheet and metal bars with a diameter of $0.005 \mathrm{~m}$, respectively. The permeability of the permeable part was $50 \%$ (Figure 2). A study of the flow pattern in the laboratory by Shokrian Hajibehzad et al. [20] demonstrated that a risk of outer bank erosion could occur in the second half of the bend as the line of maximum velocity reached the outer bank at the cross-section of $114^{\circ}$.

Although the main goal of the protection was the second half of the bend, according to Bhuiyan et al. [3], two or three structures were installed before the bend apex. Thus, the protection of the bend started from about $70^{\circ}$ cross-section and continued until the end of the bend.

In this study, four different values of distance between structures equal to $4,5,6$, and 7 times the effective length of EPG $\left(4 L_{e}, 5 L_{e}, 6 L_{e}\right.$, and $\left.7 L_{e}\right)$ were used in this experimental investigation (Figure 3) and examined under three different flow conditions at particle Froude numbers of 2.18, 2.37, and 2.55. Specifically, there were $8,7,6$, and 5 structures in $4 L_{e}, 5 L_{e}, 6 L_{e}$, and $7 L_{e}$. Table 1 lists the experimental tests that were carried out in this study.

The effective length of the enhanced permeable groin, as mentioned, was $0.14 \mathrm{~m}$, of which $0.09 \mathrm{~m}$ was permeable groin and $0.05 \mathrm{~m}$ consisted of a triangular vane. As mentioned, these dimensions were selected based on single-structure experiments reported by Ferro et al. [18]. The installation position of the first structure was considered at $67^{\circ}$ cross-section of the bend and was constant for all experiments. In all experiments, such as single-structure experiments reported by Ferro et al. [18], the water depth was constant at $0.12 \mathrm{~m}$ in the straight inlet section of the bend. The 12 experiments were performed 
under clear water conditions. After installing the structure in the desired position and leveling the bed by a bed leveler, while the end valve was completely closed, the flow control valve opened slowly until the water depth increased in the flume without any scour around the structures. In the next step, using the flow control valve and the end valve, the flow rate gradually increased while the flow depth decreased whereby the flow rate and the desired water depth $(0.12 \mathrm{~m})$ were established in the flume. This condition was kept constant for $3 \mathrm{~h}$. Then, once the channel was drained, the bed topography was scanned by a laser scanner with an accuracy of $0.0001 \mathrm{~m}$. Note that the water depth in the straight inlet section was measured by a point gage with an accuracy of $0.0001 \mathrm{~m}$.
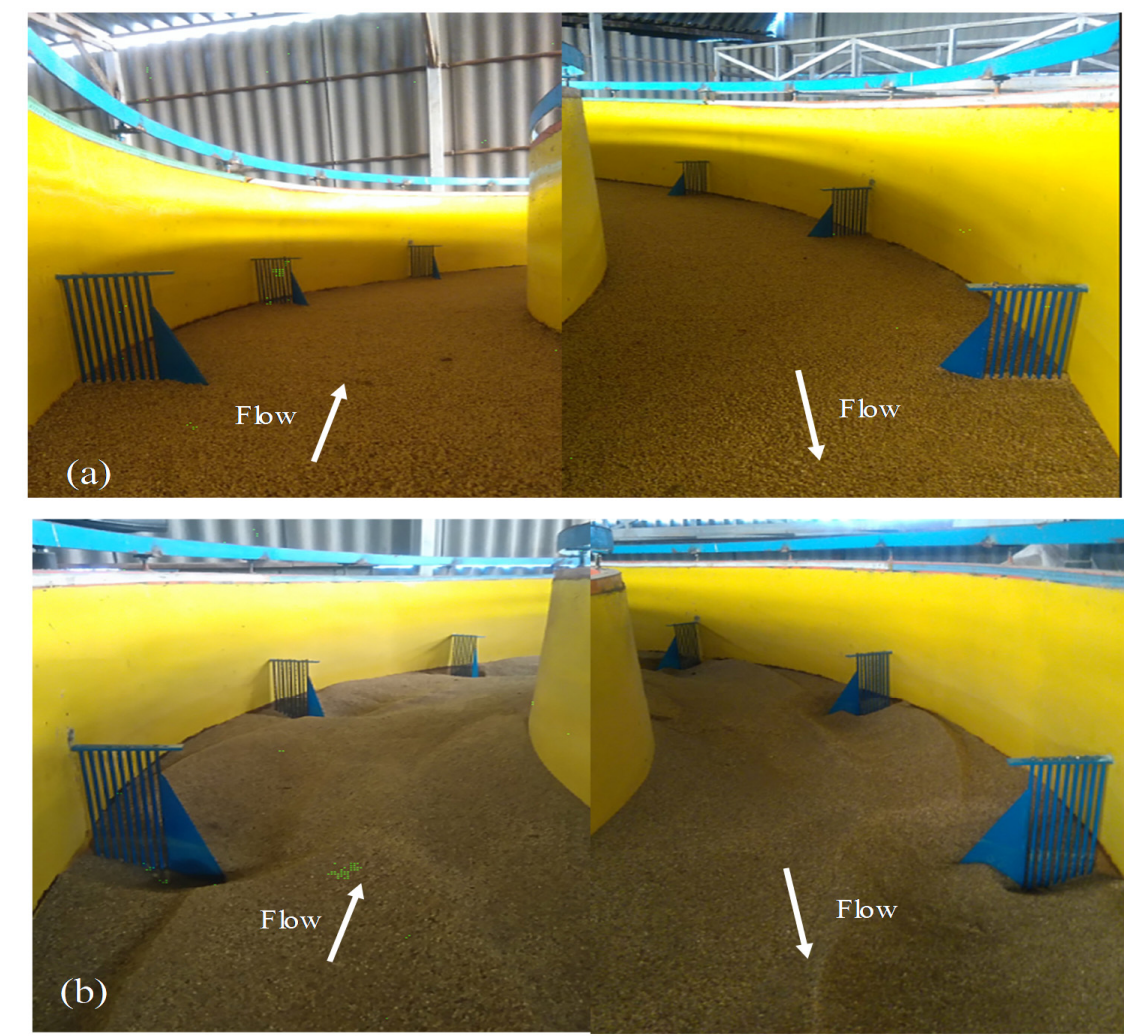

Figure 3. A view of the enhanced permeable groins installed in the bend for the experiment with the space $7 L_{e}$ before (a) and after (b) scouring.

Table 1. Description of experimental tests.

\begin{tabular}{ccccccc}
\hline Test Name & $\boldsymbol{\theta}$ (degrees) & $\boldsymbol{L}_{\boldsymbol{e}}(\mathbf{m})$ & Number of EPGs & Distance & $\begin{array}{c}\text { Water Depth } \\
\boldsymbol{h}_{\boldsymbol{w}}(\mathbf{m})\end{array}$ & $\boldsymbol{A}_{\mathbf{5 0}}$ \\
\hline T41 & 50 & 0.14 & 8 & $4 L_{e}$ & 0.12 & 2.18 \\
T42 & 50 & 0.14 & 8 & $4 L_{e}$ & 0.12 & 2.37 \\
T43 & 50 & 0.14 & 8 & $4 L_{e}$ & 0.12 & 2.55 \\
T51 & 50 & 0.14 & 7 & $5 L_{e}$ & 0.12 & 2.18 \\
T52 & 50 & 0.14 & 7 & $5 L_{e}$ & 0.12 & 2.37 \\
T53 & 50 & 0.14 & 7 & $5 L_{e}$ & 0.12 & 2.55 \\
T61 & 50 & 0.14 & 6 & $6 L_{e}$ & 0.12 & 2.18 \\
T62 & 50 & 0.14 & 6 & $6 L_{e}$ & 0.12 & 2.37 \\
T63 & 50 & 0.14 & 6 & $6 L_{e}$ & 0.12 & 2.55 \\
T71 & 50 & 0.14 & 5 & $7 L_{e}$ & 0.12 & 2.18 \\
T72 & 50 & 0.14 & 5 & $7 L_{e}$ & 0.12 & 2.37 \\
T73 & 50 & 0.14 & 5 & $7 L_{e}$ & 0.12 & 2.55 \\
\hline
\end{tabular}




\section{Results and Discussion}

\subsection{Scour and Sedimentation Process}

The scour and sedimentation patterns in the bend for EPGs with different spaces $(4,5,6$, and 7 times the effective length of the structure) under various hydraulic conditions are showed in Figures 4-6. In all experiments, the maximum scour depth occurred near the end of the first EPG, and the maximum sedimentation height formed downstream of it. As the particle Froude number increased, the maximum scour depth near the end of the EPGs, and the elevation of the sedimentation in the space between them increased.
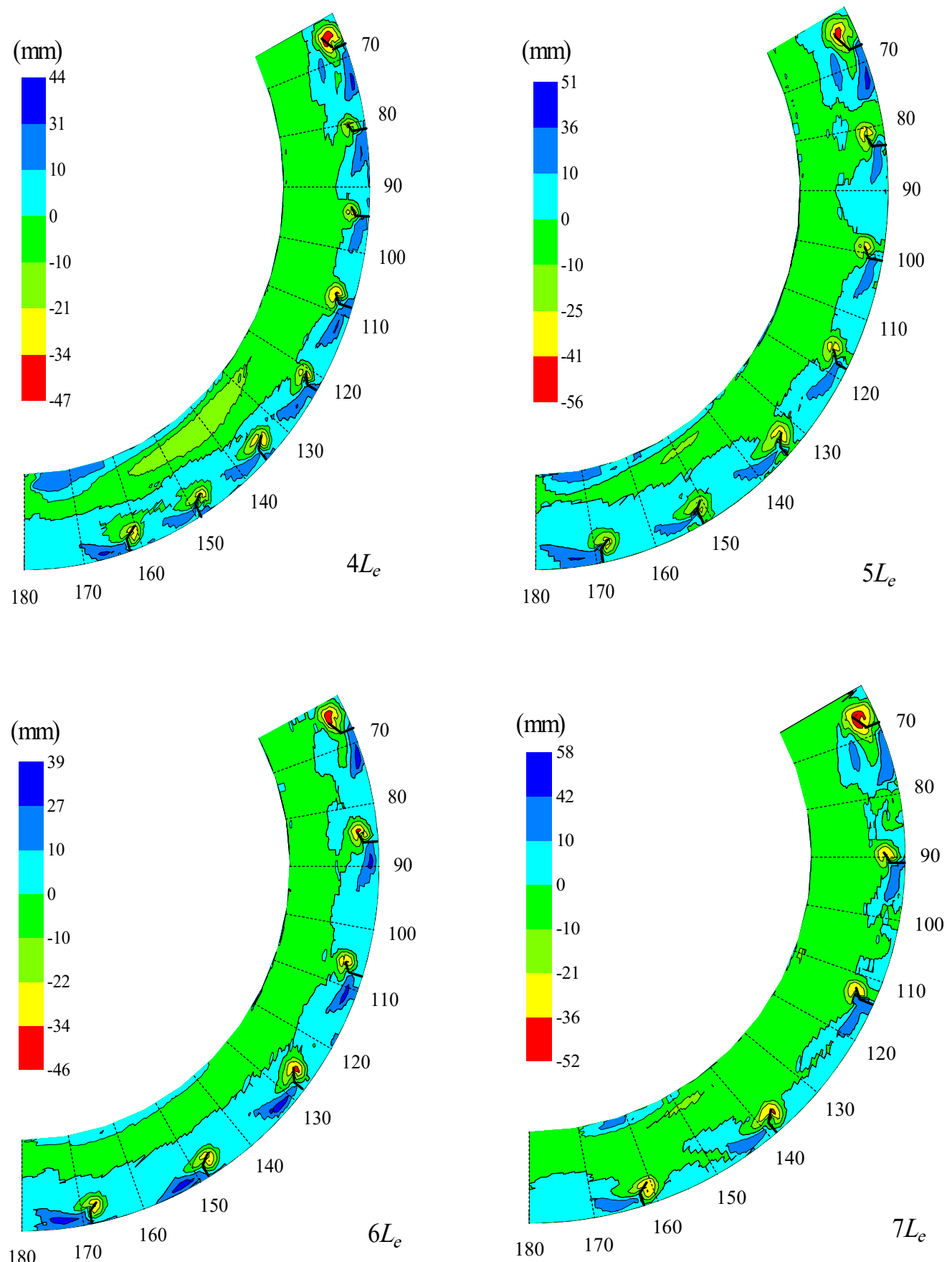

Figure 4. Bed topography variations for different distances $\left(A_{50}=2.18\right)$. 

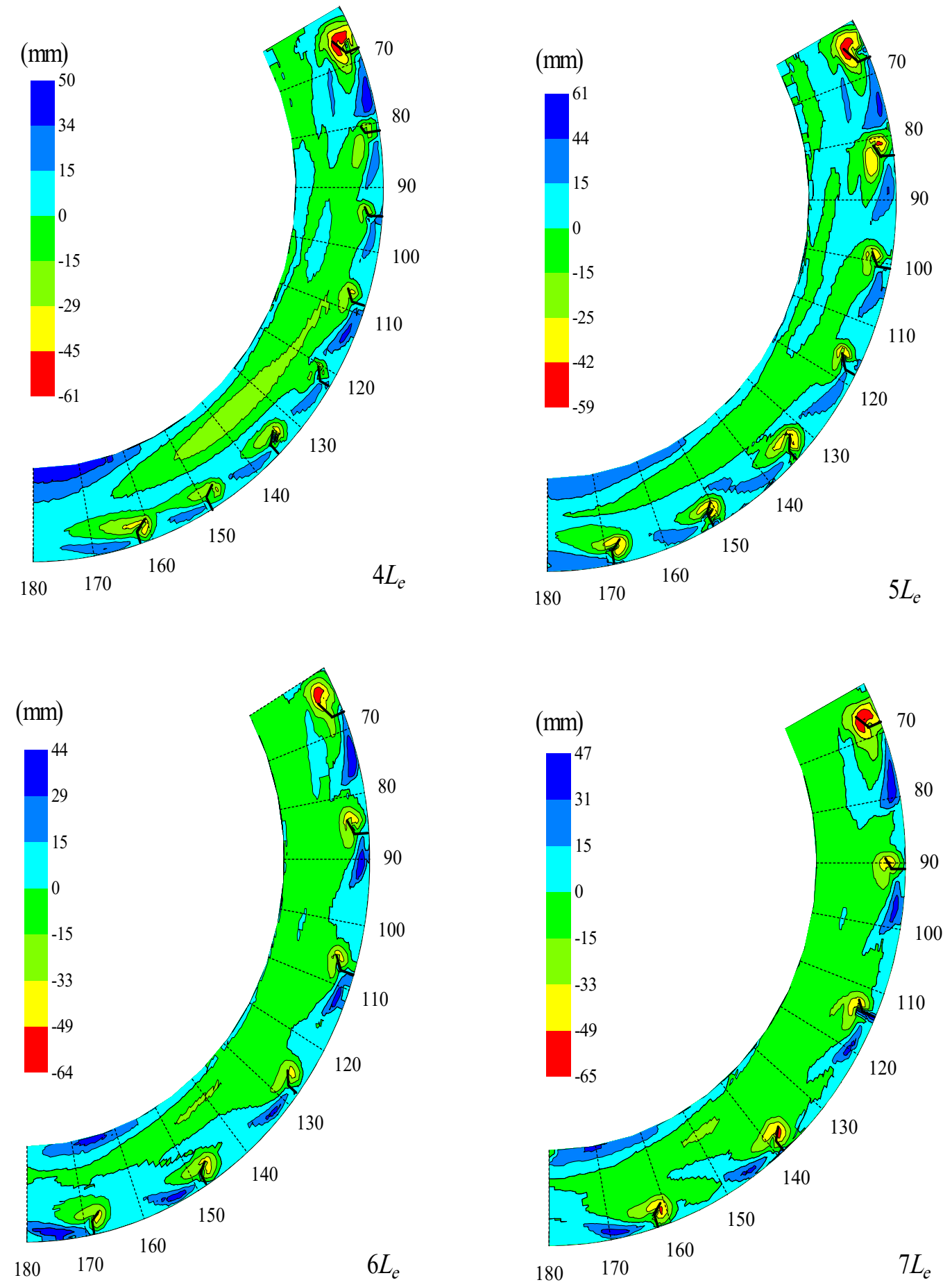

Figure 5. Bed topography variations for different distances $\left(A_{50}=2.37\right)$. 

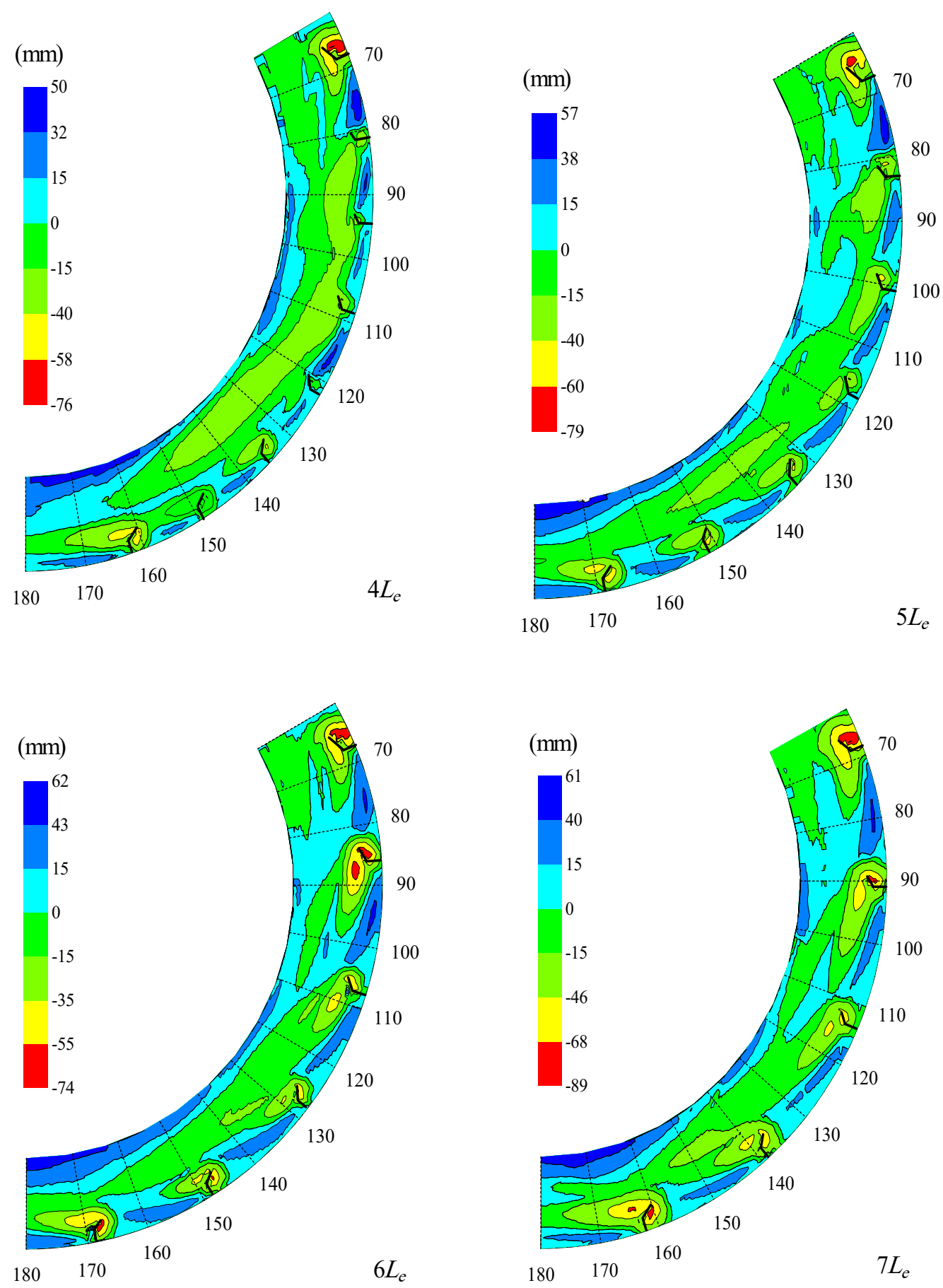

Figure 6. Bed topography variations for different distances $\left(A_{50}=2.55\right)$.

In all experiments, eroded sediments around the triangular vanes were moved by the flow towards the outer bank, which filled the zone near the outer bank and created a new bank. At all distances, the EPGs diverted the line of the maximum velocity in the regions near the outer bank toward the channel center, increasing both the bed shear stress in the middle of the channel, and the scour depth. Changes in the distance between the structures as well as the hydraulic conditions caused variations in all scour parameters between the EPGs and the position of thalweg in the channel. Observations showed that the eroded sediments around the structures were carried parallel to the axial section of the triangular vane due to the unique flow pattern formed in the regions near the bed. The eroded sediments were deposited in the zone downstream of the structures and close to the 
outer bank. The deposition of the eroded sediment can fill the scour holes near the outer bank and create a new bank. Visual observations using dye injection revealed that the group of structures could effectively deflect the line of maximum velocity from the regions near the outer bank to the middle of the channel. This function of the EPGs protects the outer bank from erosion while also increasing the amount of shear stress and scour in the middle of the channel.

\subsection{Scour Hole Characteristics around the Structures}

\subsubsection{Maximum Scour Depth}

The results revealed that in all experiments, the maximum scour depth occurred around the first EPG close to the end of the triangular vane. Predicting the maximum scour depth around river restoration structures, especially in meander bends, is very important to prevent structural instability. Figure 7 shows the cross-sectional profiles of the maximum scour depth sections around the first EPG for all experiments. The vertical axis in these figures indicates the dimensionless variations of bed topography $(z / H)$, and the horizontal axis represents the dimensionless distance from the inner bank $(Y / B)$, in which variables $z$ is the height of the bed variations, $Y$ is the distance from the inner bank, $H$ is the height of the triangular vane $\left(H=h_{w}\right)$, and $B$ is the channel width, respectively. Thus, $Y / B$ equal to 0 and 1 correspond to the inner and outer banks, respectively, which are located at the cross-sectional area of the maximum scour depth around the first EPG. Additionally, in Figure 7d, the diagram of the dimensionless maximum scour depth $\left(S_{m} / H\right)$ for different hydraulic conditions, and the distances is presented to show its effect on changes in the maximum scour depth around the first EPG. Figure 7d demonstrates that, for particle Froude numbers of 2.18 and 2.37, the changes in the distance between the structures have no significant effect on the maximum scour depth around the first EPG. However, for particle Froude numbers higher than 2.55, increasing the distance between the structures augments the maximum scour depth. For the highest particle Froude number, the maximum scour depth around the first EPG increased by increasing the distance from $4 L_{e}$ to $5 L_{e}, 6 L_{e}$, and $7 L_{e}$ by $3.34,6.35$, and $11.15 \%$, respectively.
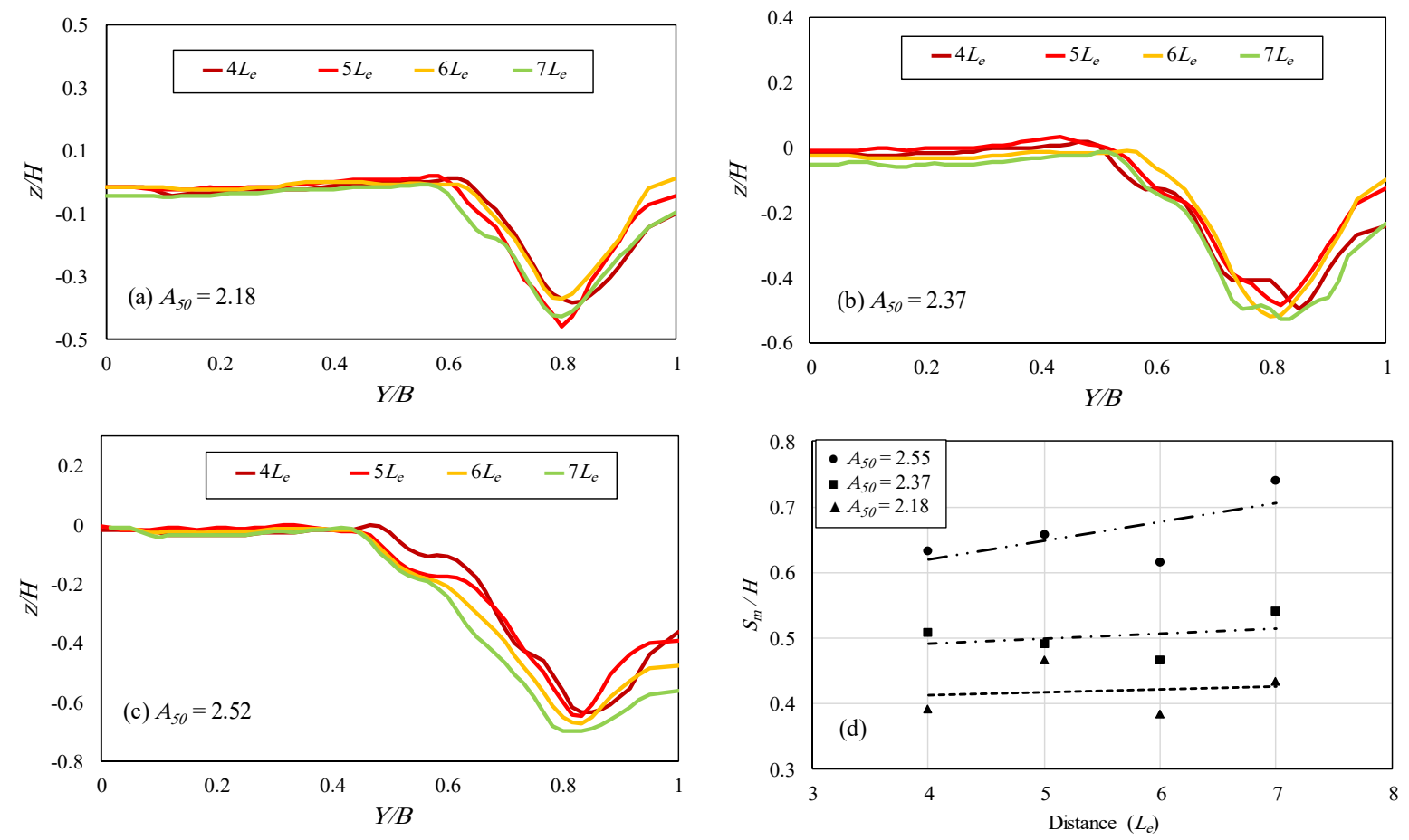

Figure 7. Cross sections of maximum scour depth and variations of maximum scour depth (d) at different distances and hydraulic conditions. (a) $A_{50}=2.18$ (b) $A_{50}=2.37$ (c) $A_{50}=2.52$. 
Ferro et al. [18] proposed the following theoretically based equations to estimate the main scour characteristics such as maximum scour depth $S_{m}$, maximum scour width $w_{s}$, maximum scour length $L_{s}$ and maximum length $L_{d}$ and height $d_{m}$ of the ridge around a single enhanced permeable groin located in $114^{\circ}$ cross-section of the bend:

$$
\begin{gathered}
\frac{S_{m}}{H}=\left(4.78 \sin \theta^{0.42}-2.9 \sin \theta-1.69\right)\left(\frac{L_{t}}{L_{p}}\right)^{0.193}\left(A_{50}-0.75\right)^{1.643} \\
\frac{w_{s}}{H}=\left(21.83 \sin \theta^{0.437}-13.04 \sin \theta-7.497\right)\left(\frac{L_{t}}{L_{p}}\right)^{0.141}\left(A_{50}-0.75\right)^{1.652} \\
\frac{L_{s}}{H}=2.092 \sin \theta^{0.263}\left(\frac{L_{t}}{L_{P}}\right)^{0.241}\left(A_{50}-0.75\right)^{2.621} \\
\frac{L_{d}}{H}=2.959 \sin \theta^{0.314}\left(\frac{L_{t}}{L_{p}}\right)^{0.31}\left(A_{50}-0.75\right)^{2.5} \\
\frac{d_{m}}{H}=0.291 \sin \theta^{-0.309}\left(\frac{L_{t}}{L_{p}}\right)^{0.343}\left(A_{50}-0.75\right)^{1.344}
\end{gathered}
$$

in which $H$ is the height of the triangular vane, $\theta$ is the angle of the triangular vane relative to the bank tangent, $L_{p}$ is the length of the permeable groin, $L_{t}$ is the effective length of the triangular vane and $A_{50}$ is the particle Froude number introduced by D'Agostino and Ferro [21] having the following expression:

$$
A_{50}=\frac{Q}{B H\left[g d_{50}\left(\frac{\rho_{s}-\rho}{\rho}\right)\right]^{1 / 2}}
$$

in which $B$ is the channel width, $Q$ is the discharge, $H$ is the water depth equal to the height of the triangular vane, $\rho$ is the water density, $g$ is the acceleration due to gravity, $\rho_{s}$ is the bed material density, and $d_{50}$ is the median particle diameter.

The mean error (absolute percentage error) of Equation (1) to estimate the maximum scour depth around the first EPG in the case with structures in the series is presented in Table 2. The results show that the estimate by Equation (1) of the maximum scour depth can be, on average, $27.45 \%$ higher than the experimental value. The main reason for this result is due to the position of the structure in the experiments by Ferro et al. [18] in which the location of the single EPG was in $114^{\circ}$ cross-section where the high-velocity zone reached the outer bank, while in the $67^{\circ}$ cross-section the distance of the destructive flow from the outer bank is further and therefore leads to less scouring. For calculating the maximum scour depth around the first EPG of structures in series, the following Equation (7) was calibrated by the experimental data of this investigation:

$$
\frac{S_{m}}{H}=\left(3.46 \sin \theta^{0.42}-2.01 \sin \theta-1.22\right)\left(\frac{L_{t}}{L_{p}}\right)^{0.193}\left(A_{50}-0.75\right)^{1.643}
$$

Equation (7) can be used to estimate the maximum scour depth with an average error of $6.5 \%$. In all experiments, the maximum scour depth occurred behind the axis of the triangular vane, inclined to the outer bank and close to the tip of the structure. Table 3 shows the characteristics of the maximum scour depth around the first EPG and the maximum scour depth of thalweg $\left(Z_{m}\right)$ at various experimental tests. This table indicates that in all the tests, except for test T42, the maximum scour depth occurred at $x / B<0.84$ in which $x$ is the distance of the location of the maximum scour depth from the inner bank. Overall, the distance of the location of the maximum scour depth from the inner bank for distances of $4 L_{e}, 5 L_{e}, 6 L_{e}$ and $7 L_{e}$ was $0.844,0.821,0.821$, and 0.818 times $B$, respectively. As mentioned, in the present study, structures with effective lengths of $23 \%$ of the width of the flume were used. 
The transverse profiles demonstrated that the maximum scour depth is located at a distance of about $17.5 \%$ of the flume width from the outer bank.

Table 2. Comparison between experimental and estimated parameters by equations 1 to 5 around the first EPG.

\begin{tabular}{|c|c|c|c|c|c|c|c|}
\hline Variables & Distance & $A_{50}$ & $S_{m} / H$ & $w_{s} / H$ & $L_{S} / H$ & $d_{m} / H$ & $L_{d} / H$ \\
\hline \multirow{3}{*}{ Estimated } & - & 2.18 & 0.59 & 3.24 & 4.30 & 0.41 & 5.51 \\
\hline & - & 2.37 & 0.72 & 4.17 & 5.96 & 0.49 & 7.53 \\
\hline & - & 2.55 & 0.86 & 4.96 & 7.86 & 0.56 & 9.80 \\
\hline \multirow{3}{*}{ Experimental } & $4 \mathrm{Le}$ & 2.18 & 0.39 & 1.66 & 2.66 & 0.28 & 4.66 \\
\hline & $4 \mathrm{Le}$ & 2.37 & 0.51 & 2.33 & 3.33 & 0.41 & 7.58 \\
\hline & $4 \mathrm{Le}$ & 2.55 & 0.63 & 2.33 & 3.33 & 0.36 & 4.41 \\
\hline \multirow{3}{*}{ Error \% } & $4 \mathrm{Le}$ & 2.18 & 34 & 48 & 38 & 32 & 15 \\
\hline & $4 \mathrm{Le}$ & 2.37 & 29 & 44 & 44 & 16 & 0 \\
\hline & $4 \mathrm{Le}$ & 2.55 & 27 & 53 & 57 & 36 & 55 \\
\hline \multirow{3}{*}{ Experimental } & $5 \mathrm{Le}$ & 2.18 & 0.46 & 1.83 & 3.33 & 0.37 & 3.33 \\
\hline & $5 \mathrm{Le}$ & 2.37 & 0.49 & 2.08 & 3.75 & 0.42 & 3.75 \\
\hline & $5 \mathrm{Le}$ & 2.55 & 0.66 & 2.58 & 4.5 & 0.42 & 5.83 \\
\hline \multirow{3}{*}{ Error \% } & $5 \mathrm{Le}$ & 2.18 & 21 & 43 & 22 & 10 & 39 \\
\hline & $5 \mathrm{Le}$ & 2.37 & 32 & 50 & 37 & 14 & 50 \\
\hline & $5 \mathrm{Le}$ & 2.55 & 23 & 48 & 43 & 25 & 40 \\
\hline \multirow{3}{*}{ Experimental } & $6 \mathrm{Le}$ & 2.18 & 0.38 & 1.5 & 2.5 & 0.31 & 3.30 \\
\hline & $6 \mathrm{Le}$ & 2.37 & 0.46 & 1.75 & 3.33 & 0.36 & 5 \\
\hline & $6 \mathrm{Le}$ & 2.55 & 0.62 & 2.25 & 3.75 & 0.40 & 5 \\
\hline \multirow{3}{*}{ Error \% } & $6 \mathrm{Le}$ & 2.18 & 35 & 54 & 42 & 24 & 40 \\
\hline & $6 \mathrm{Le}$ & 2.37 & 35 & 58 & 44 & 26 & 33 \\
\hline & $6 \mathrm{Le}$ & 2.55 & 28 & 55 & 52 & 28 & 49 \\
\hline \multirow{3}{*}{ Experimental } & $7 \mathrm{Le}$ & 2.18 & 0.43 & 1.92 & 2.08 & 0.23 & 3.30 \\
\hline & 7Le & 2.37 & 0.54 & 2.16 & 3.33 & 0.36 & 4.16 \\
\hline & 7Le & 2.55 & 0.74 & 2.41 & 3.33 & 0.37 & 4.50 \\
\hline \multirow{3}{*}{ Error \% } & 7Le & 2.18 & 27 & 41 & 51 & 44 & 40 \\
\hline & 7Le & 2.37 & 25 & 48 & 44 & 26 & 45 \\
\hline & 7Le & 2.55 & 14 & 51 & 57 & 34 & 54 \\
\hline Mean Error \% & & & 27.45 & 49.51 & 44.43 & 26.32 & 38.46 \\
\hline
\end{tabular}

Table 3. Characteristics of maximum scour depth at different tests.

\begin{tabular}{ccccccc}
\hline Test Name & $\boldsymbol{S}_{\boldsymbol{m}}(\boldsymbol{m})$ & $\boldsymbol{S}_{\boldsymbol{m}} / \boldsymbol{H}$ & $\boldsymbol{x}(\mathbf{m})$ & $\boldsymbol{x} / \boldsymbol{B}$ & $\boldsymbol{Z}_{\boldsymbol{m}}(\boldsymbol{m})$ & $\boldsymbol{Z}_{\boldsymbol{m}} / \boldsymbol{H}$ \\
\hline $\mathrm{T} 41$ & 0.047 & 0.39 & 0.499 & 0.833 & 0.018 & 0.15 \\
$\mathrm{~T} 42$ & 0.06 & 0.5 & 0.519 & 0.866 & 0.021 & 0.175 \\
$\mathrm{~T} 43$ & 0.075 & 0.63 & 0.499 & 0.833 & 0.03 & 0.25 \\
$\mathrm{~T} 51$ & 0.055 & 0.46 & 0.489 & 0.816 & 0.012 & 0.10 \\
T52 & 0.059 & 0.49 & 0.489 & 0.816 & 0.014 & 0.116 \\
T53 & 0.078 & 0.65 & 0.499 & 0.833 & 0.019 & 0.158 \\
T61 & 0.046 & 0.38 & 0.489 & 0.816 & 0.007 & 0.06 \\
T62 & 0.064 & 0.53 & 0.489 & 0.816 & 0.016 & 0.133 \\
T63 & 0.08 & 0.67 & 0.499 & 0.833 & 0.018 & 0.15 \\
T71 & 0.052 & 0.43 & 0.486 & 0.811 & 0.011 & 0.09 \\
T72 & 0.065 & 0.54 & 0.499 & 0.833 & 0.017 & 0.141 \\
T73 & 0.084 & 0.7 & 0.487 & 0.812 & 0.028 & 0.233 \\
\hline
\end{tabular}


A study by Bhuiyan et al. [3] also showed that in series of triangular vanes with an effective length of $30 \%$ of the width of the flume, the distance of the maximum scour depth from the outer bank was equal to $25 \%$ of the flume width.

The relationship between the maximum scour depth occurred around the first EPG, and the maximum scour depth in the other EPGs required to be studied.

Figure 8 illustrates the relationship between the maximum scour depth around the first EPG with the maximum scour depth around other EPGs in series. In this figure, the horizontal axis represents the number of EPGs, $N_{E P G}$. For example, $N_{E P G}=2$ presents the second enhanced permeable groin from the upstream of the bend.
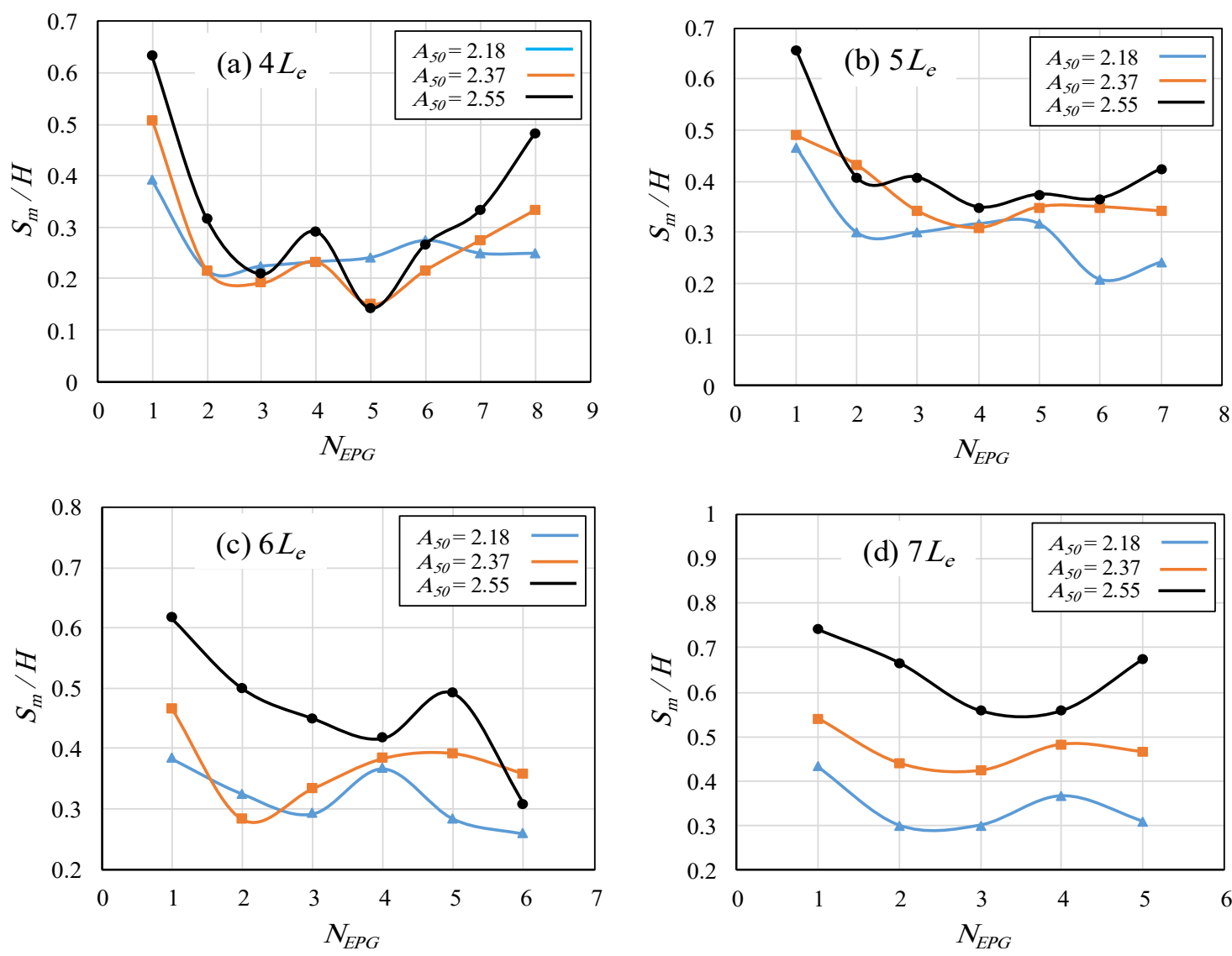

Figure 8. Relationship between the maximum scour depth occurred around the first enhanced permeable groin (EPG) and the maximum scour depth in the other EPGs at different distances and hydraulic conditions. (a) $4 L_{e}$, (b) $5 L_{e}$, (c) $6 L_{e}$, and (d) $7 L_{e}$.

The results indicate that, with increasing distance between EPGs, the maximum scour depth around the structures generally increases in all particle Froude numbers. Figure 8a shows that in the first EPG and two last EPGs, the maximum scour depth increases with increasing particle Froude number. However, from the second EPG to the sixth EPG, it is observed that the maximum scour depth does not increase with hydraulic conditions due to the effect of the upstream groin that fills the downstream scour hole. For example, in the fifth EPG, the maximum scour depth at the particle Froude number of 2.18 is higher than the others.

As mentioned, the main reason for this behavior is the effect of the upstream EPG. Figure $8 b-\mathrm{d}$ demonstrate that, as the distance between the EPGs increases, the impact of the structures on each other decreases so that, at a distance of $7 L_{e}$, the structures are functionally independent; this will increase the maximum scour depth around the structures and raise their risk of destruction by extending scour holes toward the outer bank. 


\subsubsection{Maximum Scour Width}

The maximum scour width is another significant variable that should be investigated because it is directly related to the stability of the protective structure and the outer bank. Furthermore, the development of scour holes toward the outer bank occurs by increasing the width of the scour hole, especially in the case of structures in series in which longer lengths of the outer bank can be affected. Figure 9 shows the relationship between the maximum scour width around the first EPG and the maximum scour width around other EPGs at different distances and hydraulic conditions. Figure 9a indicates that in the last EPG (eighth EPG) the maximum scour width increases with increasing particle Froude number, while this is not true in previous EPGs. For example, Figure 9a reveals that when the particle Froude number is the maximum $\left(A_{50}=2.55\right)$, the maximum scour width in the third and fifth EPGs are the lowest. Additionally, in Figure 9b, it can be seen that in the first EPG and last two EPGs, the width of the scour holes increases with increasing hydraulic conditions, which indicates their independent function. Similar to the maximum scour depth, it is observed that by increasing the distance between the structures, the maximum scour width increases in general, which is mainly due to the decrease in the impact of the structures on each other. Figure $9 \mathrm{c}, \mathrm{d}$ also show that, except for the sixth and second EPGs, respectively, the performance of the other EPGs is independent of each other, which cannot be considered positively from the outer bank protection point of view. The mean error of Equation (2) to calculate the maximum scour width around the first EPG is also shown in Table 2. The results indicate that Equation (2) overestimates the maximum scour width with an average error of $49.51 \%$. The following Equation (8), which has the same mathematical shape as Equation (2) and was calibrated by the measurements carried out in this investigation, can be used to calculate the maximum scour width around the first EPG with an average error of $7.8 \%$ :

$$
\frac{w_{s}}{H}=\left(11.03 \sin \theta^{0.437}-6.59 \sin \theta-3.79\right)\left(\frac{L_{t}}{L_{p}}\right)^{0.141}\left(A_{50}-0.75\right)^{1.652}
$$
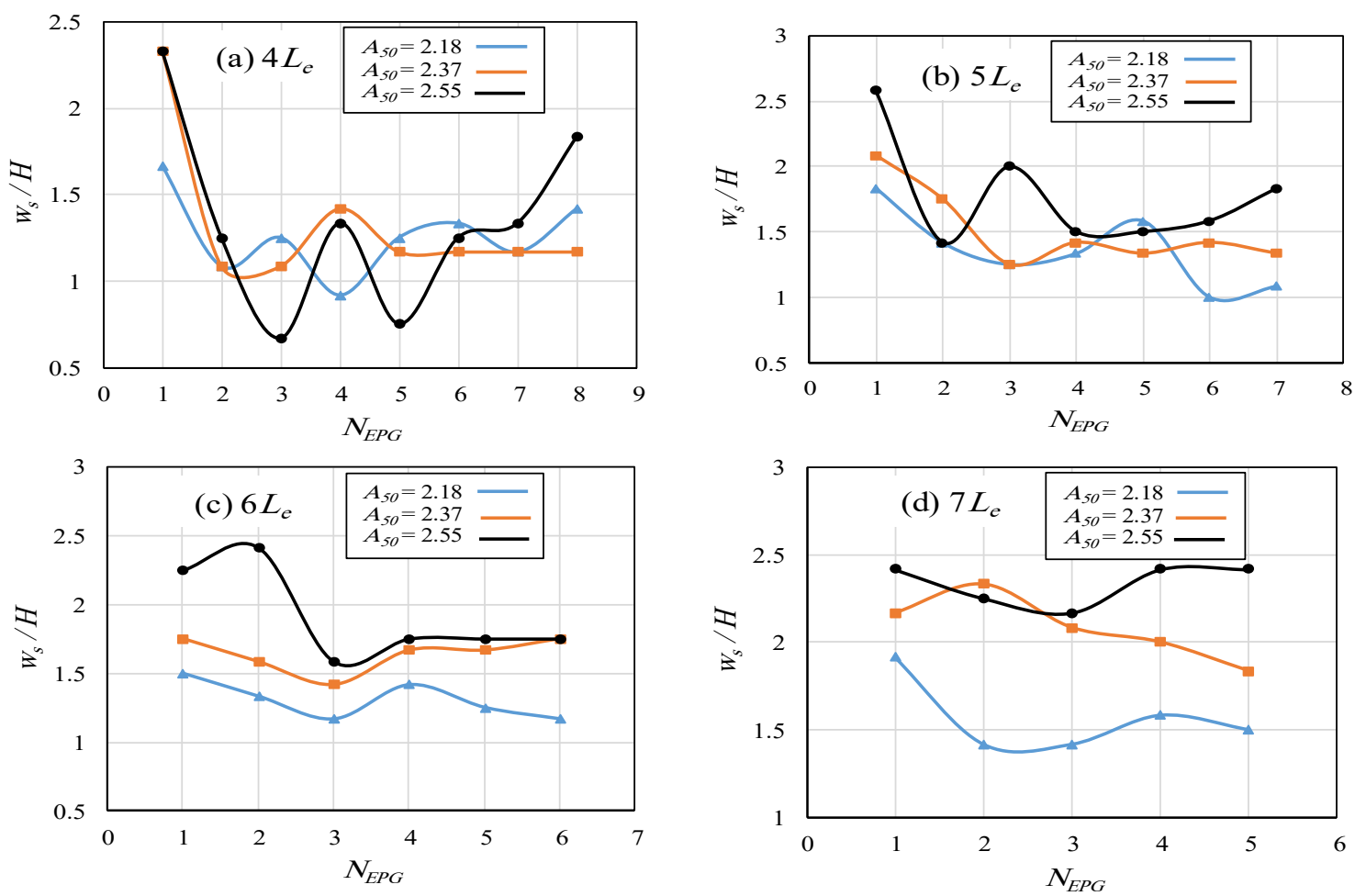

Figure 9. Relationship between the maximum scour width occurred around the first EPG and the maximum scour depth in the other EPGs at different distances. (a) $4 L_{e}$, (b) $5 L_{e}$, (c) $6 L_{e}$, and (d) $7 L_{e}$. 


\subsubsection{Maximum Scour Length}

Another significant variable of the scouring phenomenon around riverbank protection structures is the maximum scour length. The relationship between the maximum scour length around the first EPG, and other EPGs at different distances and hydraulic conditions is shown in Figure 10. Figure 10a shows that only in the last two EPGs the maximum scour length increases as the particle Froude number increases. For example, from the second to the fifth EPG, the minimum scour lengths occur in the case with the maximum particle Froude number. As mentioned earlier, this is due to the effect of the structures on each other. In contrast to the maximum scour depth, and maximum scour width, it seems that the maximum scour length decreases with increasing distance between structures. Besides, the effect of the structures on each other decreases. The results of Table 2 show that the mean error of Equation (3) to estimate the maximum scour length around the first EPG in the case with structures in series $44.43 \%$. The following Equation (9) was calibrated using the experimental data of this investigation and can be used to calculate the maximum scour length with an average error of $12.3 \%$.

$$
\frac{L_{s}}{H}=1.16 \sin \theta^{0.263}\left(\frac{L_{t}}{L_{P}}\right)^{0.241}\left(A_{50}-0.75\right)^{2.621}
$$
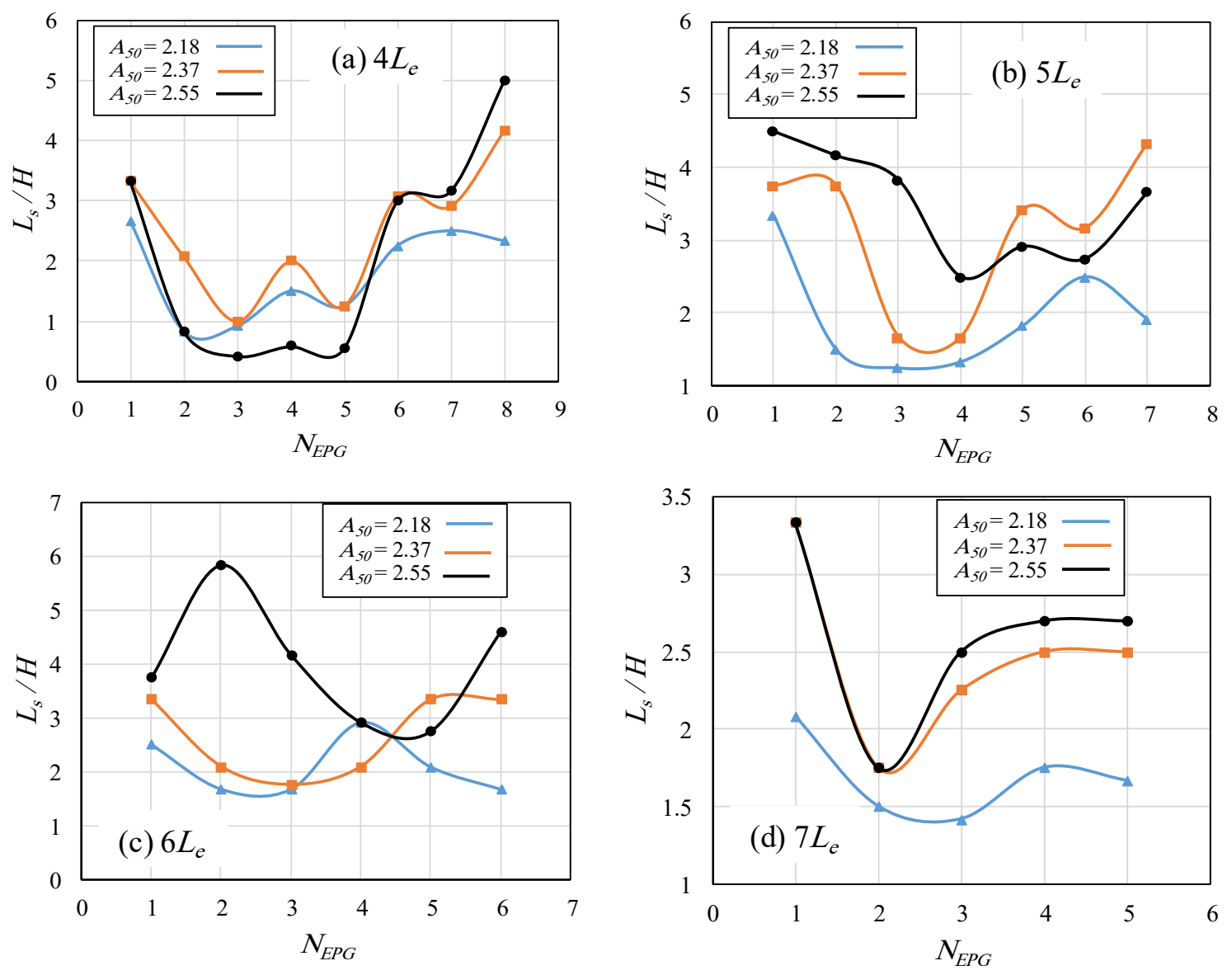

Figure 10. Relationship between the maximum scour length occurred around the first EPG and the maximum scour length in the other EPGs at different distances and hydraulic conditions. (a) $4 L_{e}$, (b) $5 L_{e}$, (c) $6 L_{e}$, and (d) $7 L_{e}$. 


\subsection{Sediment Deposition Zone Characteristics around the Structures}

\subsubsection{Maximum Ridge Height}

In river restoration projects, in addition to controlling the outer bank scour using groin-type structures, filling the scour holes close to the outer bank and creating a new bank are also required. Erosion-induced sediments at the tip of the structures, as well as sediments that approach from the upstream, are affected by the specific flow pattern formed around the triangular vanes. Thus, it is necessary to investigate the sedimentation process by the EPGs connected to the outer bank. Figures 4-6 display how eroded sediments are deposited in the distance between the EPGs and near the outer bank. Figures 11-13 indicate the cross-sectional profiles in the sections between the two consecutive EPGs for different distances and hydraulic conditions. In these figures, the letter $\mathrm{S}$ represents the structure, and its indices represent the number of two consecutive EPGs (as an example, S12 represents the cross-section between the first and second structure). As can be seen, in comparison with other distances, for all hydraulic conditions investigated for a distance equal to $4 L_{e}$, deposited sediments are closer to the outer bank. For all particle Froude numbers, as the distance between the structures increased, so did the distance between the ridge and the outer bank, and the path between the deposition zone and the outer bank became wider. Overall, the results indicate that the distance of the deposited sediments from the outer bank in the cross-sections between the structures was the lowest and highest at the spaces of $4 L_{e}$ and $7 L_{e}$, respectively. As can be seen, with the enhanced permeable groin in series with spaces of $4 L_{e}$ and $5 L_{e}$, the deposition of eroded sediments covered the scour holes around the downstream structures (Figures 4-6). However, in the spaces of $6 L_{e}$ and $7 L_{e}$, and especially at the particle Froude number of 2.55, the eroded sediments did not cover the downstream scour holes.
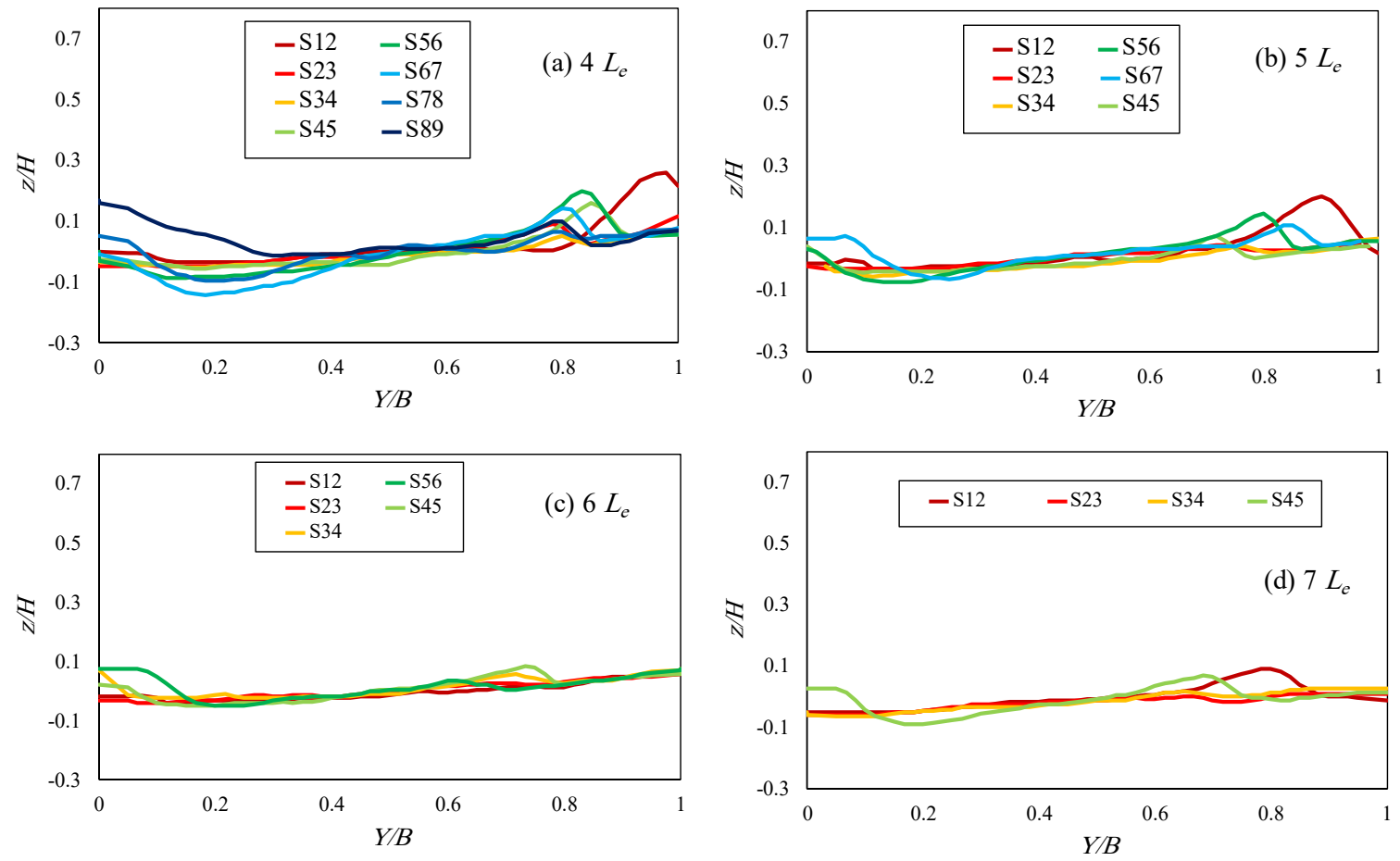

Figure 11. Cross sections between two consecutive structures at particle Froude number of 2.18. (a) $4 L_{e}$, (b) $5 L_{e},(\mathbf{c}) 6 L_{e}$, and (d) $7 L_{e}$. 

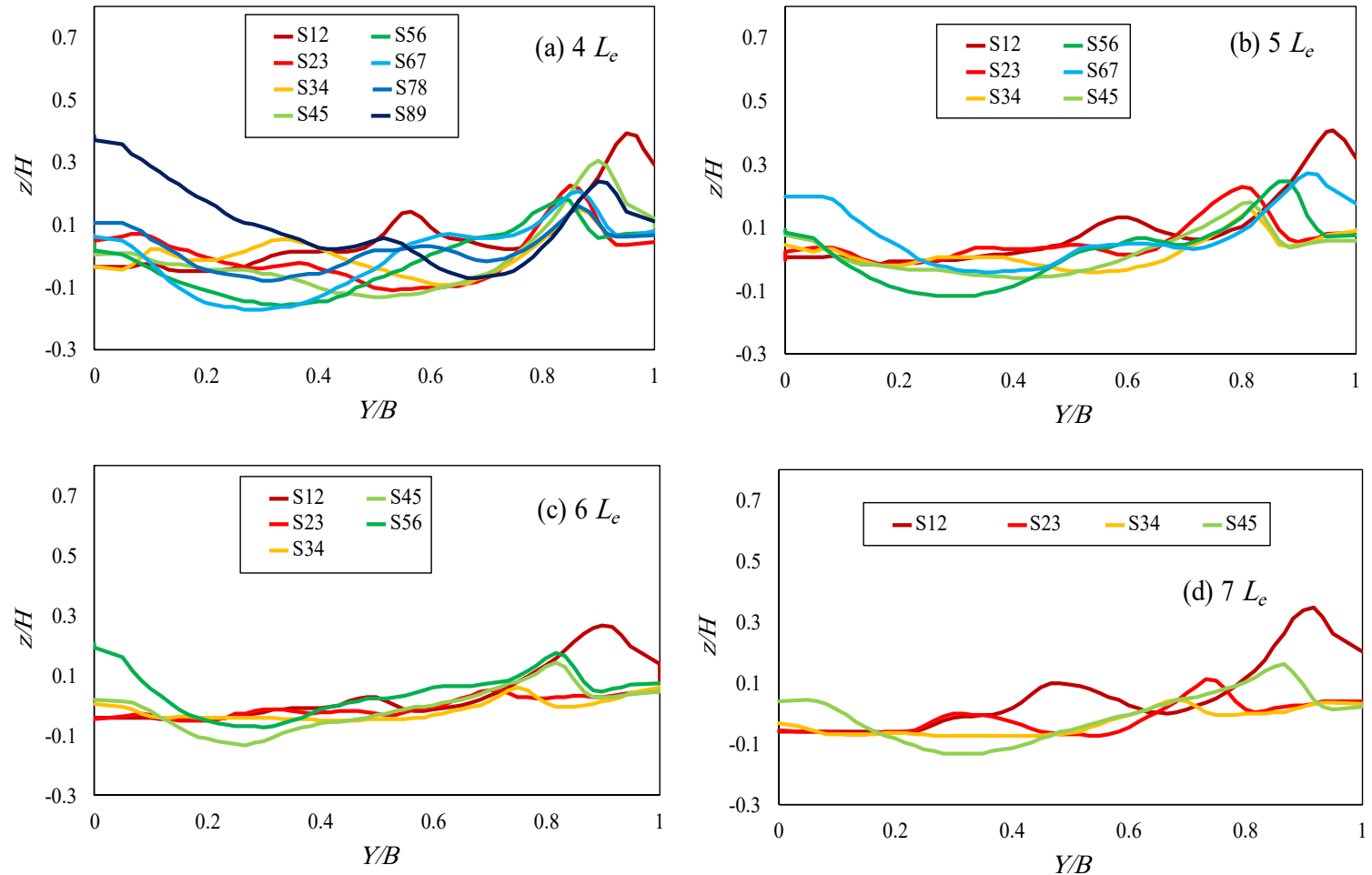

Figure 12. Cross sections between two consecutive structures at particle Froude number of 2.37. (a) $4 L_{e}$, (b) $5 L_{e},(\mathbf{c}) 6 L_{e}$, and (d) $7 L_{e}$.
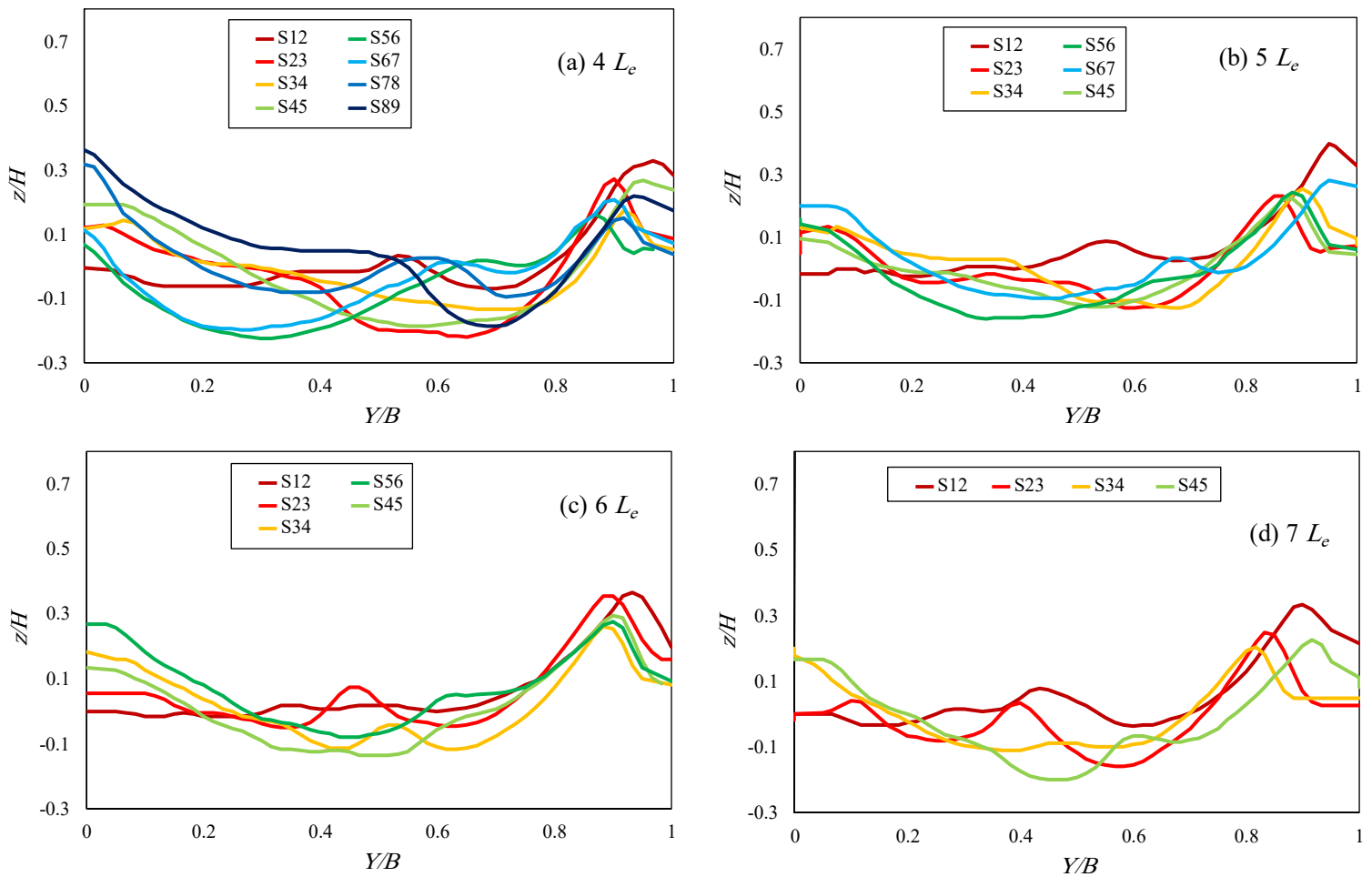

Figure 13. Cross sections between two consecutive structures at particle Froude number of 2.55. (a) $4 L_{e}$, (b) $5 L_{e},(\mathbf{c}) 6 L_{e}$, and (d) $7 L_{e}$.

Figure 14 shows the relationship between the maximum ridge height downstream of the first EPG and downstream of other EPGs. The results indicate that as the distance between the EPGs increases, the maximum ridge height between them decreases. Furthermore, due to the effect of the structures on 
each other and the complicated flow pattern that is formed in the bend, there is no direct relationship between increasing the particle Froude number and increasing the maximum ridge height. For example, in Figure 14b, the maximum ridge height at the particle Froude number of 2.37 is greater than the particle Froude number of 2.55. Additionally, Table 2 shows that similar to the scour hole characteristics, Equation (4) overestimates the maximum ridge height around the first EPG. The mean error of Equation (4) was found to be $26.32 \%$. The following Equation (10), which was calibrated by experimental data of this investigation, can be applied to calculate the maximum ridge height with an average error of $9.55 \%$ :

$$
\frac{L_{d}}{H}=2.18 \sin \theta^{0.314}\left(\frac{L_{t}}{L_{p}}\right)^{0.31}\left(A_{50}-0.75\right)^{2.5}
$$
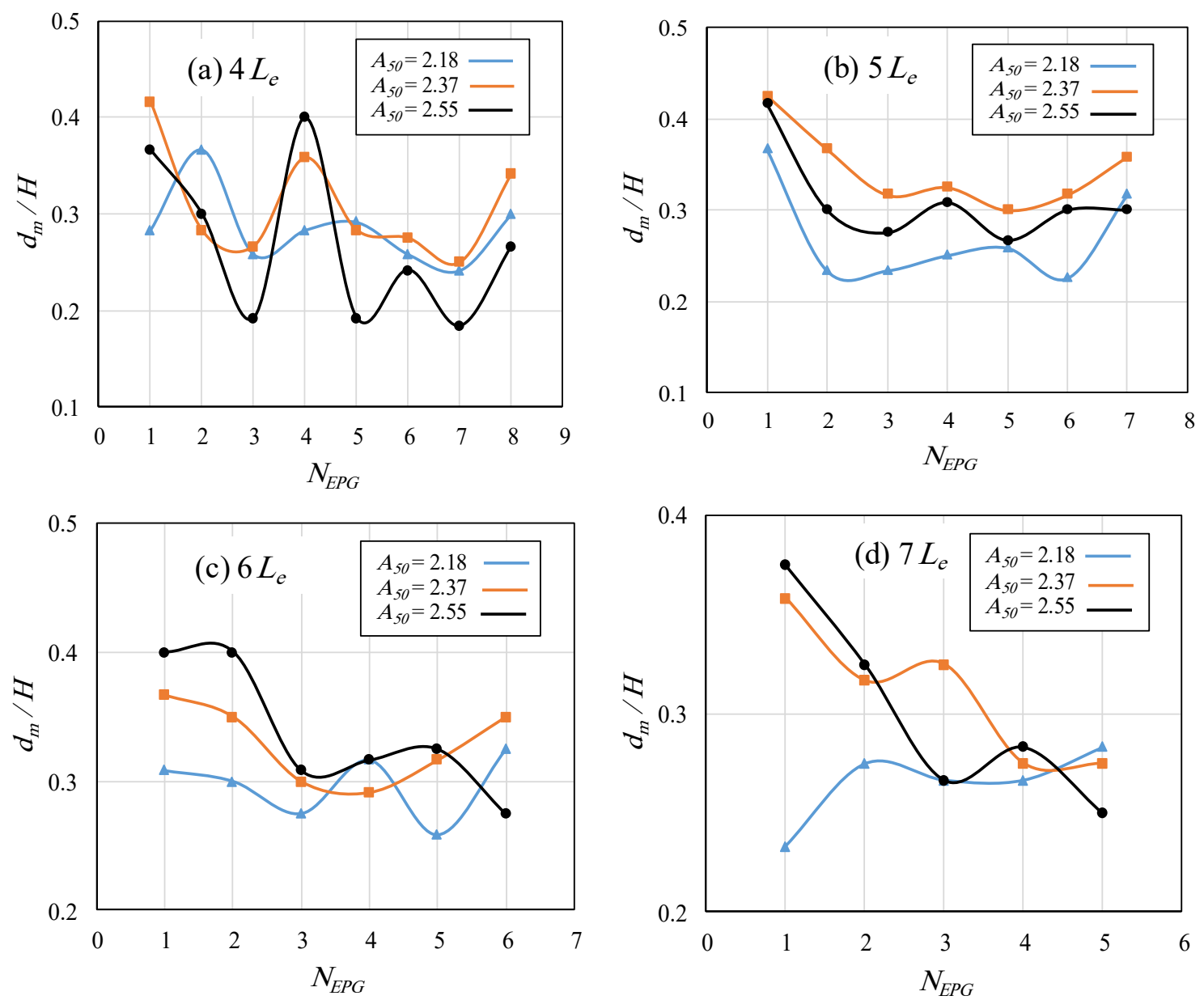

Figure 14. Relationship between the maximum scour length occurred around the first EPG and the maximum scour length in the other EPGs at different distances and hydraulic conditions. (a) $4 L_{e}$, (b) $5 L_{e},(\mathbf{c}) 6 L_{e}$, and (d) $7 L_{e}$.

\subsubsection{Maximum Ridge Length}

Another significant parameter in the design of riverbank erosion control structures, especially in the case of structures in series, is the maximum ridge length because it is an important factor in determining the distance between structures. Figure 15 shows that the maximum ridge length decreases with increasing distance between structures. As the distance between the structures increases from 5 to 6 and $7 L_{e}$, the effect of the structures on each other decreases so that their function becomes completely independent at a distance of $7 L_{e}$. In general, the results of comparing the scour-deposition parameters around the first EPG and other EPGs indicate that if the distance between the structures is more than $4 L_{e}$, the effect of the structures on each other decreases. Therefore, as a general result, for a 
$180^{\circ}$ mild bend and the investigated particle Froude numbers, a distance of $4 L_{e}$ is recommended for the structure.
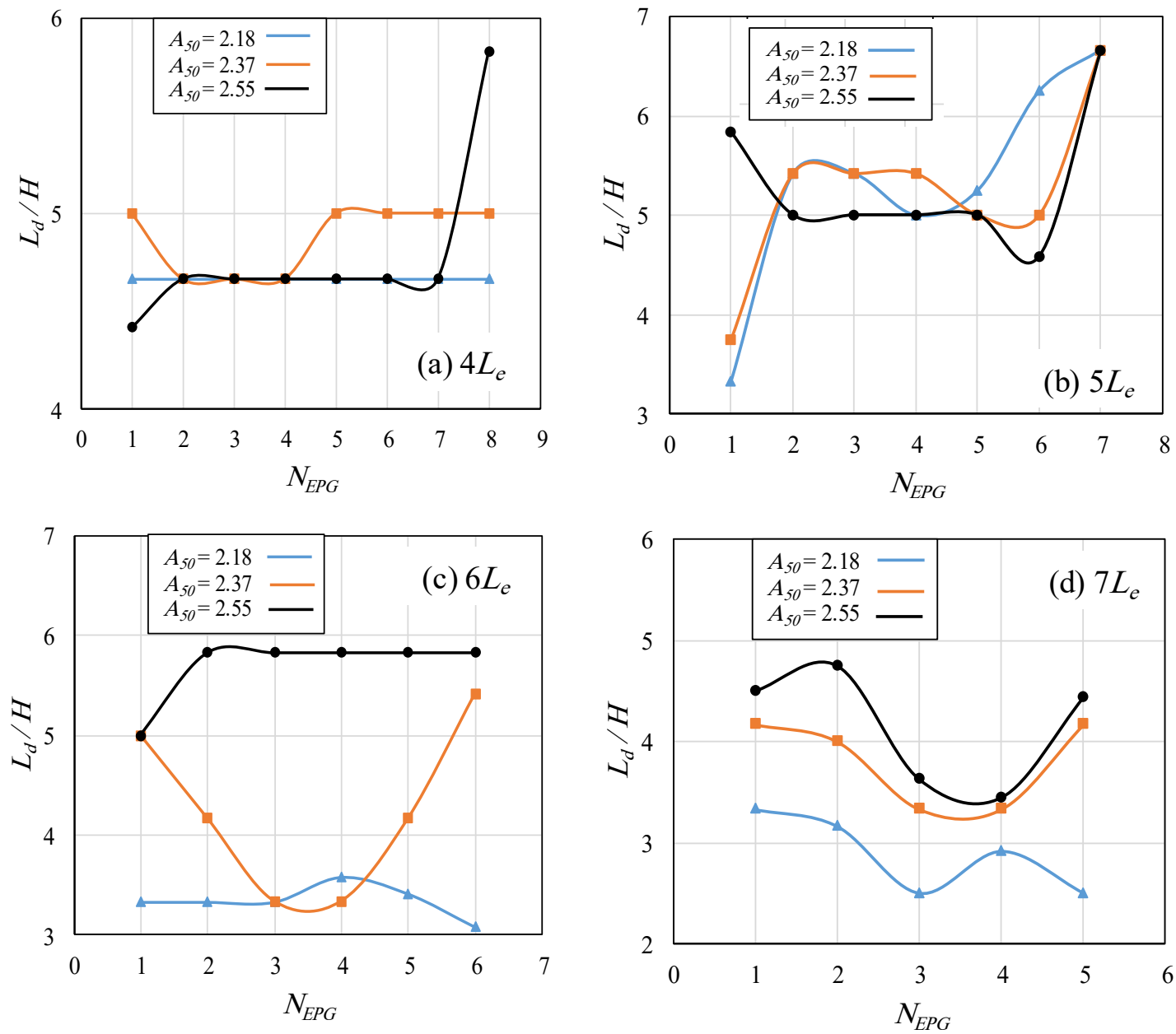

Figure 15. Relationship between the maximum ridge length occurred around the first EPG and the maximum ridge length in the other EPGs at different distances and hydraulic conditions. (a) $4 L_{e}$, (b) $5 L_{e}$, (c) $6 L_{e}$, and (d) $7 L_{e}$.

However, in cases where the suspended sediment load in the river is very high, considering more sedimentation than laboratory conditions, a distance of $5 L_{e}$ can be considered. The following Equation (11) can be used to compute the maximum ridge length around the first EPG with an average error of $18.1 \%$ :

$$
\frac{L_{d}}{H}=1.342 \sin \theta^{0.314}\left(\frac{L_{t}}{L_{p}}\right)^{0.31}\left(A_{50}-0.75\right)^{2.5}
$$

\subsection{Thalweg Characteristics}

Table 3 presents the values of the maximum scour depth of thalweg $\left(Z_{m}\right)$ at different experimental tests. It can be seen that, in the case with the space of $4 L_{e}$, the maximum scour depth at the thalweg is greater than at other distances (Figure 16). As the distance between the structures increased to $5 L_{e}$ and $6 L_{e}$, the maximum scour depth diminished. Therefore, by increasing the distance between the EPGs, the deflection of the core of the maximum longitudinal velocity from the regions near the outer bank toward the middle of the channel and consequently the bed shear stress in the middle of the channel decreased. However, in the experiments with the distance of $7 L_{e}$, the maximum scour depth of thalweg gradually increased compared to the distances of $5 L_{e}$ and $6 L_{e}$. This is mainly due to the fact 
that in the case with a distance of $7 L_{e}$ the scour holes around the structures extend toward the outer bank and middle of the channel.

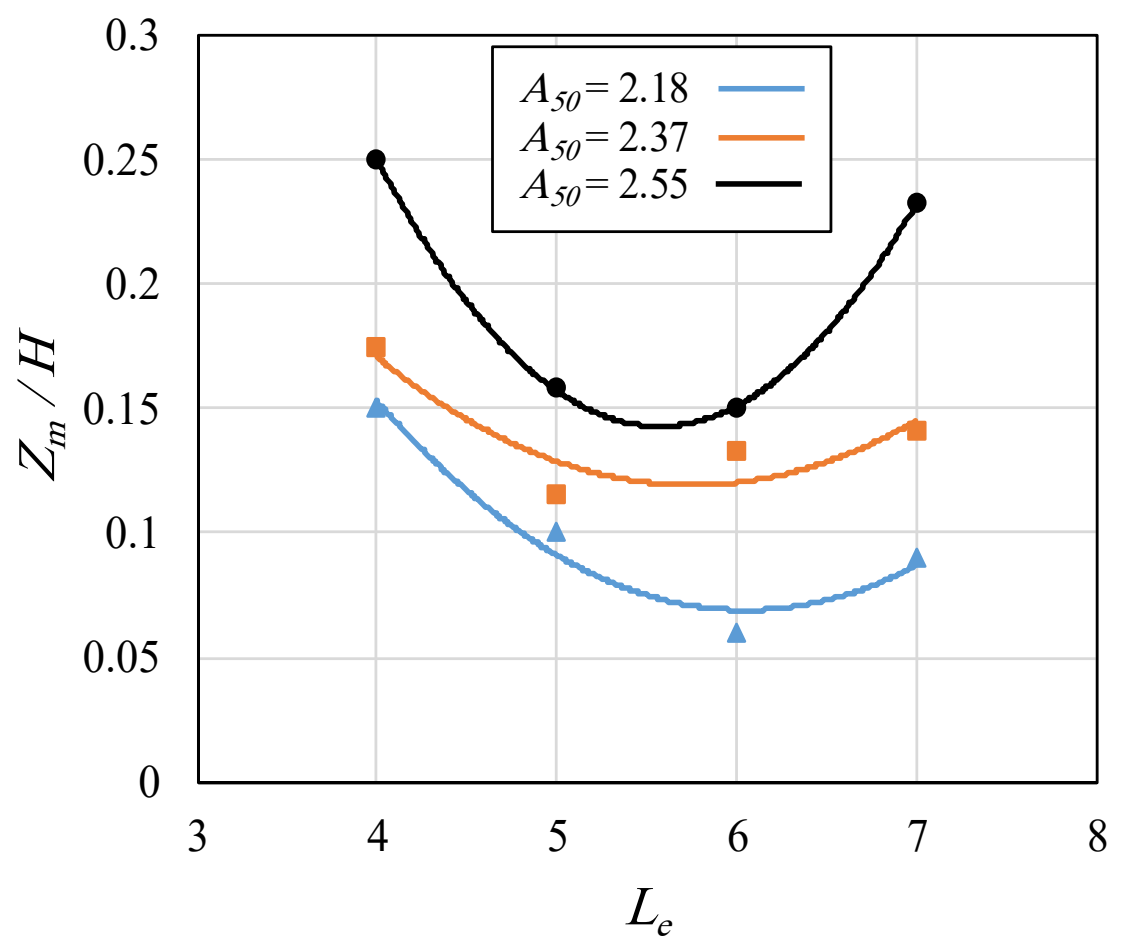

Figure 16. Variation of the maximum scour depth of thalweg with distances at different hydraulic conditions.

Figure 17 displays the plan of the thalweg variations for different experiments. When the particle Froude number increased, the position of the thalweg changed from regions close to the inner bank to the middle of the channel. For the case with particle Froude number of 2.18, it can be seen that the position of the thalweg is very close to the inner bank. Additionally, the change in the distance between the EPGs does not have a significant effect on its position. With the rise of the particle Froude number (e.g., $A_{50}=2.37$ ), an increase in the distance between the structures changed the thalweg location from the channel middle toward the regions near the inner bank. However, this behavior of the thalweg was completely reversed in the maximum particle Froude number, and as the distance between the structures increased, the position of the thalweg moved from the middle of the channel toward the regions near the outer bank. In all experiments, the thalweg formed in the inner half of the channel, suggesting the ability of the structures to move the core of the maximum velocity away from the outer bank. Visual observations using dye injection revealed that in the particle Froude numbers of 2.18, 2.37, and 2.55 the EPGs deviated the maximum velocity line to the regions near the inner bank, one-third of the flume width from the inner bank, and the channel middle, respectively. Further, Figure 18 plots the cross-sectional profiles of the maximum scour depth sections for all experiments. This figure also reveals the variation of the maximum scour depth of thalweg versus the particle Froude numbers. 


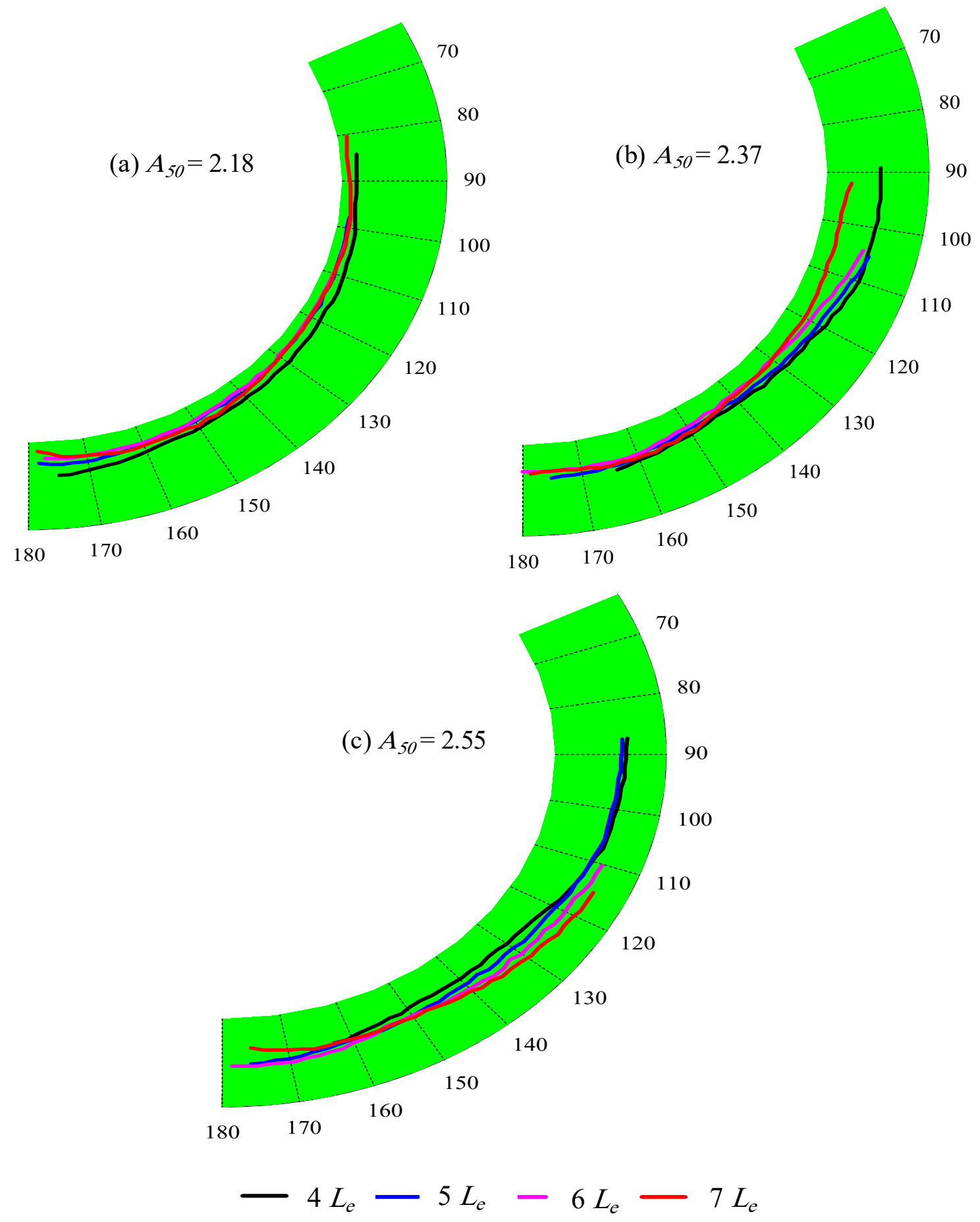

Figure 17. Variation of thalweg location at different spaces and hydraulic conditions. (a) $A_{50}=2.18$, (b) $A_{50}=2.37$, and (c) $A_{50}=2.55$. 

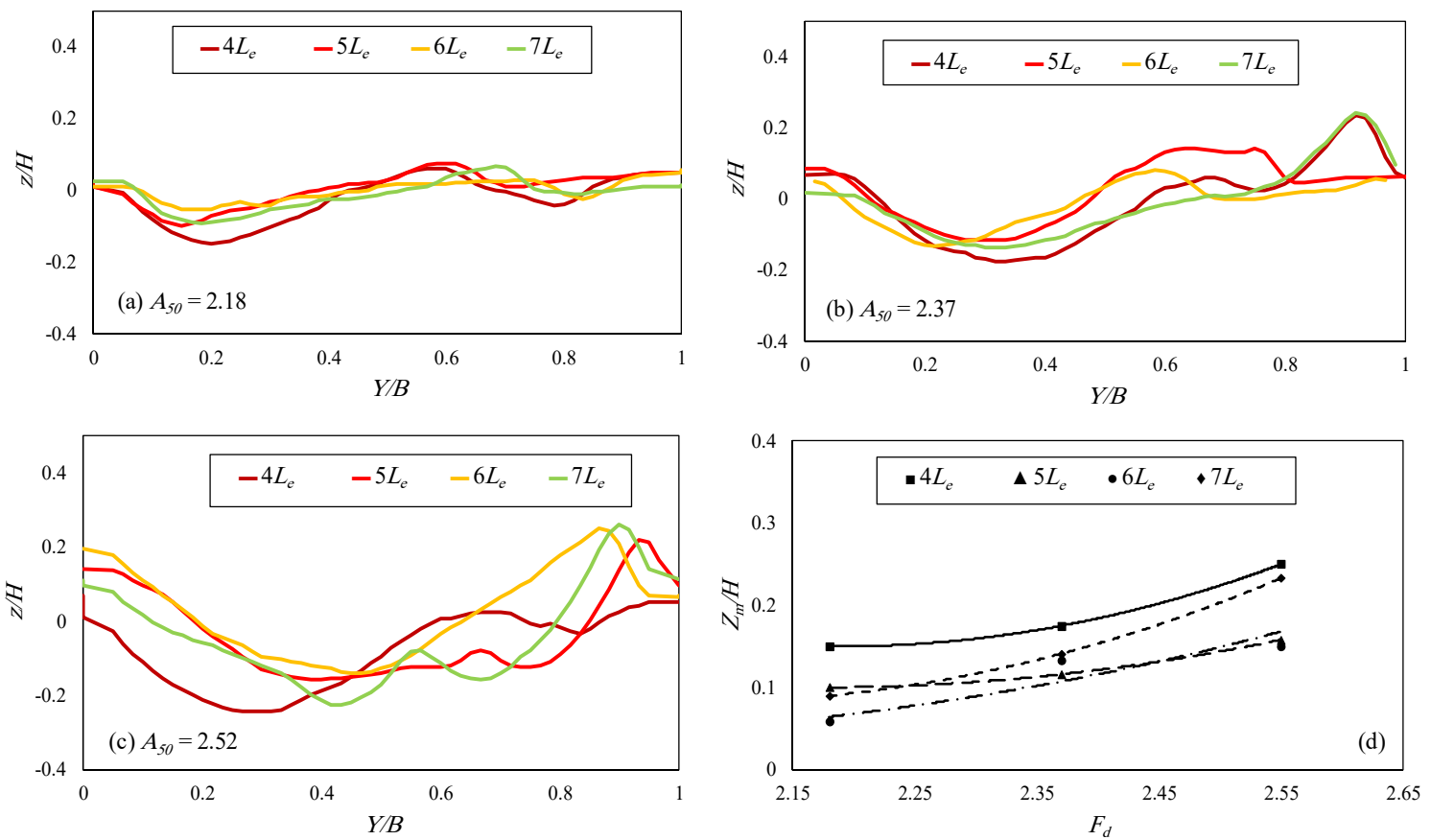

Figure 18. Cross sections of maximum thalweg depth and variations of maximum thalweg depth (d) at different distances and hydraulic conditions. (a) $A_{50}=2.18$ (b) $A_{50}=2.37$ (c) $A_{50}=2.52$.

\subsection{Design and Installation Guidelines for Applying EPGs in Series}

For a more appropriate design of EPGs in series, design variables such as (1) height of the structures (2) geometry and dimensions of the structures (3) distance between the structures and (4) installation depth of the structures in the riverbed and (5) location of the first structure in the bend should be determined. In the first stage, comprehensive information about the studied river bend should be prepared. Information such as the length of the bend to be protected, the maximum scour depth in the bend estimated using available analytical methods and its location, and other information related to the hydraulic and environmental conditions of the river.

In the next step, after measuring in field the maximum scour depth in the bend without the structure, the scour characteristics caused by the first EPG should also be calculated using new equations calibrated by the measurements of this investigation.

Therefore, the height of the structure will be equal to the sum of the initial depth of the river in the regions near the outer bank, the maximum scour depth due to the flow pattern formed in the bend and the maximum scour depth due to the presence of an EPG in the bend.

The results of this study indicated that the maximum scour depth occurs near the end of the first structure in the case with EPGs in series. Additionally, the results of this study can be used to estimate the relationship between scour characteristics around the first EPG and other EPGs in the bend.

After determining the height of the structure, the geometry and dimensions of the structures, such as the angle of the triangular vane relative to the tangent of the outer bank, the ratio between the effective lengths of the triangular vane and the permeable groin $\left(L_{t} / L_{p}\right)$, and the total effective length of the structure $\left(L_{e}\right)$ must be determined.

According to Ferro et al. [18], the triangular vane with an angle of $50^{\circ}$ and with a ratio of $L_{t} / L_{p}=0.55$ showed better performance in a $180^{\circ}$ mild flume bend. Furthermore, according to Bhuiyan et al. [3], the total effective length of the groin-type structure should not exceed $30 \%$ of the river width. Therefore, the total effective length between $20-25 \%$ of the river width is recommended by the authors.

The results of this study revealed that the distance between the structure should not be more than $4 L_{e}$ because the effect of the structures on each other reduces. However, if the amount of suspended load in the river is high, the distance between the EPGs can be considered equal to $5 L_{e}$. 
The minimum depth of trench for the installation of the triangular vanes can be estimated using the method proposed by Bhuiyan et al. [3].

To determine the position of the first structure in the bend, one or two structures must be installed before the protected interval.

The results of this research and its practical recommendations can be used in meander bends similar to $180^{\circ}$ mild bend which is in the group of moderate curvature bends.

\section{Conclusions}

The present study experimentally investigated the effects of changes in the distance between enhanced permeable groins in series on bed topography in a $180^{\circ}$ mild flume bend. Based on the results of this study, the following conclusions could be drawn:

(a) Maximum scour depth occurred around the first EPG and the location of the maximum scour depth in all experiments was near the tip of the triangular part of the structure. Data analysis showed that in particle Froude numbers 2.18 and 2.37, changes in distances between the structures have no significant effect on the maximum scour depth around the first groin, while in maximum particle Froude number 2.55, the maximum scour depth increases by $15 \%$ with increasing distance from 4 to $6 L_{e}$. Similar behavior was also observed for the maximum scour width and length.

(b) The results revealed that when the particle Froude number is the maximum $\left(A_{50}=2.55\right)$, the maximum scour width in the third and fifth EPGs are the lowest. Additionally, it is found that in the first EPG and last two EPGs, the width of the scour holes increased with raising hydraulic conditions, which indicates their independent function.

(c) From the second to the fifth EPG, the minimum scour lengths occurred in the case with the maximum particle Froude number, which was mainly due to the effect of the structures on each other. In contrast to the maximum scour depth and maximum scour width, the maximum scour length diminished with increasing distance between structures.

(d) Deposited sediments were found to be closer to the outer bank for all hydraulic conditions investigated for a distance equal to $4 L_{e}$, compared to other spaces. For all particle Froude numbers, as the distance between the structures expanded, so did the distance between the ridge and the outer bank, and the path between the deposition zone and the outer bank became spacious.

(e) Enhanced permeable groins in series increased scouring in the middle of the channel by diverting the high-velocity zone to the channel center. As the particle Froude number increased or the distance between the structures decreased, the scour depth in the middle of the channel increased. Additionally, the results showed that the thalweg location tends to move toward the inner bank by reducing the distance between the groins.

(f) According to the results of this research, the distance between the EPGs should not be greater than four times the effective length of the structure. The general design guideline proposed in this study can be applied to the proper design of EPGs in series.

Author Contributions: M.S.H. prepared the manuscript, including the experimental setup, V.F. and M.S.B. provided supervision and corrected the manuscript. All authors have read and agreed to the published version of the manuscript.

Funding: This research was funded by Iran National Science Fundation (INSF) under grant number 96005198.

Conflicts of Interest: The authors declare no conflict of interest.

\section{References}

1. Lai, Y.G.; Greimann, B.P. Modeling of erosion and deposition at meandering channels. In Proceedings of the World Environmental and Water Resources Congress, Honolulu, HI, USA, 12-16 May 2008; pp. 1-11.

2. Ramkumar, M.; Kumaraswamy, K.; Mohanraj, R. Environmental Management of River Basin Ecosystems; Springer: Berlin/Heidelberg, Germany, 2015. 
3. Bhuiyan, F.; Hey, R.D.; Wormleaton, P.R. Bank-attached vanes for bank erosion control and restoration of river meanders. J. Hydraul. Eng. 2010, 136, 583-596. [CrossRef]

4. Teraguchi, H.; Nakagawa, H.; Kawaike, K.; Baba, Y.; Zhang, H. Effects of hydraulic structures on river morphological processes. Int. J. Sediment Res. 2011, 26, 283-303. [CrossRef]

5. Przedwojski, B. Bed topography and local scour in rivers with banks protected by groynes. J. Hydraul. Res. 1995, 33, 257-273. [CrossRef]

6. Rosgen, D.L. The cross-vane, w-weir and j-hook vane structures ... their description, design and application for stream stabilization and river restoration. Wetl. Eng. River Restor. 2001, 12, 1-22.

7. Bhuiyan, F.; Hey, R.D.; Wormleaton, P.R. Hydraulic evaluation of W-weir for river restoration. J. Hydraul. Eng. 2007, 133, 596-609. [CrossRef]

8. Pagliara, S.; Kurdistani, S.M.; Santucci, I. Scour downstream of J-Hook vanes in straight horizontal channels. Acta Geophys. 2013, 61, 1211-1228. [CrossRef]

9. Pagliara, S.; Kurdistani, S.M. Clear water scour at J-Hook Vanes in channel bends for stream restorations. Ecol. Eng. 2015, 83, 386-393. [CrossRef]

10. Uijttewaal, W.S.J.; Lehmann, D.; Van Mazijk, A. Exchange processes between a river and its groyne fields: Model experiments. J. Hydraul. Eng. 2001, 127, 928-936. [CrossRef]

11. Fukuoka, S.; Nakagawa, N.; Sumi, T.; Zhang, H. Advances in River Sediment Research; Taylor \& Francis Group: London, UK, 2013.

12. Hayashida, H.; Muto, Y.; Tazoe, S.; Tamura, T. Scour and deposition around spur dykes with head works. In Proceedings of the 12th International Symposium on River Sedimentation, ISRS, Kyoto, Japan, 2-5 September 2013; pp. 98-102.

13. Pandey, M. Flow Pattern and Scour around Multiple Spur-Dikes in Channels. Master's Thesis, Indian Institute of Technology, Roorkee, India, 2014.

14. Tominaga, A.; Sadat, S. Combination of permeable and impermeable spur dikes to reduce local scour and to create diverse river bed. In River Sedimentation, Proceedings of the 13th International Symposium on River Sedimentation, Stuttgart, Germany, 19-22 September 2016; CRC Press: Stuttgart, Germany, 2016; pp. $19-22$.

15. Dey, S.; Barbhuiya, A.K. Time variation of scour at abutments. J. Hydraul. Eng. 2005, 131, 11-23. [CrossRef]

16. Gu, Z.; Cao, X.; Gu, Q.; Lu, W.-Z. Exploring Proper Spacing Threshold of Non-Submerged Spur Dikes with Ipsilateral Layout. Water 2020, 12, 172. [CrossRef]

17. Yarahmadi, M.B.; Bejestan, M.S. Sediment management and flow patterns at river bend due to triangular vanes attached to the bank. J. Hydro-Environ. Res. 2016, 10, 64-75. [CrossRef]

18. Ferro, V.; Hajibehzad, M.S.; Bejestan, M.S.; Kashefipour, S.M. Scour around a Permeable Groin Combined with a Triangular Vane in River Bends. J. Irrig. Drain. Eng. 2019, 145, 04019003. [CrossRef]

19. Blanckaert, K.; Duarte, A.; Chen, Q.; Schleiss, A.J. Flow processes near smooth and rough (concave) outer banks in curved open channels. J. Geophys. Res. Earth Surf. 2012, 117, F04020. [CrossRef]

20. Hajibehzad, M.S.; Ferro, V.; Bejestan, M.S.; Kashefipour, M. Mean Flow and turbulence structure around and enhanced permeable groin in river bends. Water. Resources. Res. 2020, in press.

21. D'Agostino, V.; Ferro, V. Scour on alluvial bed downstream of grade-control structures. J. Hydraul. Eng. 2004, 130, 24-37. [CrossRef]

Publisher's Note: MDPI stays neutral with regard to jurisdictional claims in published maps and institutional affiliations.

(C) 2020 by the authors. Licensee MDPI, Basel, Switzerland. This article is an open access article distributed under the terms and conditions of the Creative Commons Attribution (CC BY) license (http://creativecommons.org/licenses/by/4.0/). 